Santa Clara University

Scholar Commons

Accounting

Leavey School of Business

$9-2009$

\title{
Market uncertainty and disclosure of internal control deficiencies under the Sarbanes-Oxley Act
}

\author{
Yongtae Kim \\ Santa Clara University, y1kim@scu.edu
}

Myung Seok Park

Follow this and additional works at: http://scholarcommons.scu.edu/accounting

Part of the Accounting Commons

\section{Recommended Citation}

Kim, Yongtae, and Myung Seok Park. "Market Uncertainty and Disclosure of Internal Control Deficiencies under the Sarbanes-Oxley Act." Journal of Accounting and Public Policy 28.5 (2009): 419-45.

NOTICE: this is the author's version of a work that was accepted for publication in Journal of Accounting and Public Policy. Changes resulting from the publishing process, such as peer review, editing, corrections, structural formatting, and other quality control mechanisms may not be reflected in this document. Changes may have been made to this work since it was submitted for publication. A definitive version was subsequently published in Journal of Accounting and Public Policy, Vol. 28, No. 5, (2009) doi:10.1016/j.jaccpubpol.2009.07.004

This Article is brought to you for free and open access by the Leavey School of Business at Scholar Commons. It has been accepted for inclusion in Accounting by an authorized administrator of Scholar Commons. For more information, please contact rscroggin@scu.edu. 


\title{
Market Uncertainty and Disclosure of Internal Control Deficiencies Under the Sarbanes-Oxley Act
}

\author{
Yongtae Kim \\ Leavey School of Business \\ Santa Clara University \\ Santa Clara, CA 95053-0380 \\ Myung Seok Park* \\ School of Business \\ Virginia Commonwealth University \\ Richmond, VA 23284-4000
}

*Correspondence to: Myung Seok Park, Ph. D.

Department of Accounting, School of Business

Virginia Commonwealth University

Snead Hall, 301 W. Main St., P.O. Box 844000

Richmond, VA 23284-4000

Tel: (804) 828-3161; Fax:(804) 828-8884

Email: mspark@vcu.edu

\section{Acknowledgements}

We are grateful to Martin Loeb (editor), two anonymous reviewers, and workshop participants at the 2006 American Accounting Association annual meeting, 2006 European Accounting Association annual congress, Sogang University, SungKyunKwan University, and Virginia Commonwealth University for their comments. Kim acknowledges financial support provided by Leavey Research Grant and a Breetwor Fellowship. Park acknowledges financial support from School of Business at Virginia Commonwealth University. 


\title{
Market Uncertainty and the Disclosure of Internal Control Deficiencies Under the Sarbanes-Oxley Act
}

\begin{abstract}
This study examines cross-sectional differences in stock market reactions to the disclosure of internal control deficiencies under Section 302 of the Sarbanes-Oxley Act. We hypothesize that the market punishment for internal control problems will be less severe for internal control disclosure that helps reduce market uncertainty around the disclosure. We also predict that such a relation is dependent on the types of disclosure and the market's prior knowledge of the credibility of firms' financial reporting. Consistent with our hypothesis, we find that when firms disclose their internal control deficiencies, their abnormal stock returns are negatively associated with changes in market uncertainty (e.g., changes in the standard deviations of daily stock returns) around the disclosure. We also find that the impact of the uncertainty reduction is greater for voluntary disclosures of non-material weakness, especially those made in the context of previous suspicious events. The negative impact of changes in market uncertainty on the abnormal stock returns remains intact even after controlling for possible simultaneity. An analysis using financial analysts' earnings forecasts dispersion as an alternative proxy for uncertainty confirms the results.
\end{abstract}

Keywords: Disclosures; Internal control deficiencies; Market uncertainty; Sarbanes-Oxley Act

JEL Descriptors: M41, M42, G14, G30 


\section{Market Uncertainty and the Disclosure of Internal Control Deficiencies Under the Sarbanes-Oxley Act}

\section{Introduction}

This study examines the costs and benefits of the disclosure of a firm's internal control deficiencies under Section 302. ${ }^{1}$ Specifically, we investigate whether the market reaction to such disclosure is less negative when the disclosure reduces market uncertainty. We argue that while correcting internal control deficiencies has a negative effect on the expected value of cash flows, internal control disclosures (hereafter ICDs) can increase or decrease market uncertainty, and thereby lead to different market reactions around ICDs.

The Financial Accounting Standards Board (FASB) states that firms can improve their reporting by voluntarily disclosing more information in which the investment community and shareholders have a keen interest. ${ }^{2}$ Easley and O'Hara (2004) suggest that the information risk arising from poor information quality affects the firm's cost of capital. They demonstrate that by providing credible information, a firm can lower the risk premium, and thus reduce its cost of capital. Our uncertainty construct, the standard deviations of stock returns, is closely related to that of Easley and O'Hara (2004).

Franco, Guan, and $\mathrm{Lu}(2005)$ find that the cumulative, size-adjusted, abnormal returns are $-1.8 \%$ during the three-day event window for firms that report internal control deficiencies under Section 302. Hammersley, Myers, and Shakespeare (2008) examine the stock-price reaction to the disclosure of internal control weaknesses and to disclosure characteristics. They provide empirical evidence that the severity of internal control weaknesses, management's conclusion regarding the effectiveness of the

\footnotetext{
${ }^{1}$ Sections 302 and 404 of the Sarbanes-Oxley Act of 2002 (SOX) require new compliance regarding firms' internal control systems. Section 302 of the SOX requires that management evaluate the effectiveness of disclosure controls, disclose all significant deficiencies and material weaknesses to the auditors and audit committee, and report significant changes in the company's internal controls. However, Section 302 does not require public disclosure of deficiencies less severe than material weakness. Any public disclosure of non-material weakness, therefore, is potentially voluntary. Section 404 of the SOX, effective for fiscal years ending on or after November 15, 2004, requires auditors' attestation reports on both the firm's internal controls and management's assessment of the company's internal controls over financial reporting.

${ }^{2}$ See the FASB's report, "Improving Business Reporting: Insights into Enhancing Voluntary Disclosures" (March 2001).
} 
controls, the auditability of internal control weaknesses, and the vagueness of the disclosure are informative in explaining stock price reaction to internal control weakness disclosures. Although closely related, our study differs from Franco et al. (2005) and Hammersley et al. (2008). By considering the effect of ICD on market uncertainty, our study focuses on the impact of changes in market uncertainty on the cross-sectional difference in market reactions to the disclosure of internal control deficiencies.

Prior empirical research (Beneish, Billings, and Hodder 2008; Ogneva, Subramanyam, and Raghunanthan 2007; Ashbaugh-Skaife, Collins, Kinney, and LaFond 2008) documents the relation between the cost of equity capital and ICDs. Beneish et al. (2008) examine the capital market effects of material weaknesses disclosures under Sections 302 and 404 of the SOX. They provide empirical evidence that Section 302 disclosures are associated with negative, abnormal returns of -1.8 percent, and that disclosing firms experience an abnormal increase in the cost of capital of 68 base points. However, they find no significant stock price or cost of equity effects associated with Section 404 disclosures. ${ }^{3}$ Ogneva et al. (2007) examine the association between the implied cost of equity and internal control effectiveness for firms that filed Section 404 reports with the SEC. They conclude that internal control weaknesses are not directly associated, on average, with a higher implied cost of equity. Ashbaugh-Skaife et al. (2008) find that firms with internal control deficiencies have significantly higher idiosyncratic risk, systematic risk, and cost of equity capital. They also find that firms disclosing ineffective internal control under Section 302 but subsequently improving their internal controls, as evidenced by an unqualified SOX 404 audit opinion, exhibit a decrease in the cost of capital. While Ashbaugh-Skaife et al. (2008) document the higher cost of equity capital for firms with internal control deficiencies, we single out market uncertainty changes as an important factor that contributes to the relation between the cost of capital and ICDs. We further examine the impact of different disclosure attributes on changes in uncertainty and the relation between market uncertainty and market reactions around ICDs.

\footnotetext{
${ }^{3}$ Beneish et al. (2008) argue that the disclosure of internal control problems is uncertainty-increasing for disclosing firms. In contrast, we assume that an ICD can increase or decrease market uncertainty for disclosing firms depending on the types of disclosure and the market's prior knowledge of the credibility of firms' financial reporting and that market reactions are dependent on the change in uncertainty induced by such internal control revelations.
} 
In this study, we predict that if the ICD decreases (increases) uncertainty about firm value, resulting in a lower (higher) discount rate, then market reactions to such disclosure will be less (more) negative. For deficiencies less severe than material weakness, Section 302 does not require public disclosure. However, managers may choose to disclose such information voluntarily to reduce market uncertainty and/or litigation risk (Skinner 1994, 1997). Costs associated with voluntary disclosure (including proprietary costs and negative surprises from bad news disclosure) can be substantial. Managers have an incentive to voluntarily disclose non-material weaknesses only when the benefit of disclosure is large enough. Hence, we conjecture that the voluntary disclosure of internal control weaknesses is more likely to reduce market uncertainty. Given the nature of voluntary disclosures, investors would expect a decrease in uncertainty from a voluntary disclosure of non-material weaknesses. If investors perceive the voluntary disclosure of internal control problems as an uncertainty-clearing disclosure, then market reactions to such a disclosure would be less negative. Thus, we also argue that the market reaction to uncertainty change is more pronounced for voluntary ICDs. Furthermore, changes in market uncertainty and their impact on returns around the ICDs would be dependent on the market's prior knowledge of the firms' financial reporting credibility. ${ }^{4}$ That is, investors can view a firm's ICD in the context of their prior beliefs regarding the effectiveness of the firm's financial reporting systems. When the market has suspected a firm's internal control problem prior to public disclosure, disclosure of nonmaterial internal control deficiencies can reduce uncertainty and the impact of the uncertainty reduction would be greater. ${ }^{5}$

\footnotetext{
${ }^{4}$ In this study, we use the incidence of prior events as a proxy for the market's prior knowledge, which might give the market a clue about the firm's internal control deficiency. These prior events include earnings restatements, management changes, auditor changes, delayed filing, SEC investigations, internal control issues, and other accounting problems. Details on this empirical proxy are discussed in the later section.

${ }_{5}$ The following case serves well as an illustrative example. Intelligroup, Inc. voluntarily disclosed a non-material internal control weakness on October 1,2004. The company previously announced the restatement of its financial statements on September 24, 2004 and hired a new CFO on April 5, 2004. Upon the disclosure of a non-material ICD, the company experienced a reduction in market uncertainty (i.e., the standard deviation of stock returns decreased by about ten percent) and positive abnormal stock returns during the three day period around the ICD disclosure.
} 
Using the market-adjusted, abnormal returns over a three-day event window (day -1 to +1 ) surrounding the ICDs, we provide evidence that when a firm discloses its internal control deficiencies under Section 302, its abnormal stock returns are negatively associated with a change in the standard deviation of daily stock returns. We interpret this result to mean that when the disclosure of internal control deficiencies reduces uncertainty in the market (e.g., a decrease in the standard deviation of stock returns), it has a less negative impact on stock prices. We find that under Section 302, voluntary disclosure of non-material weaknesses tends to reduce uncertainty, especially when the market has suspected the effectiveness of the firm's internal controls. However, these results disappear when we control for simultaneity. We also find that the negative relation between changes in the standard deviation of stock returns and abnormal returns is more pronounced when a firm voluntarily discloses its nonmaterial internal control deficiencies, and especially when the voluntary disclosure is made in the context of previous suspicious events. An analysis using financial analysts' earnings forecast dispersion as an alternative proxy for uncertainty confirms the results.

Our study contributes to the accounting literature by providing an important incentive for and clarifying the impact of bad news disclosure. Our evidence suggests that firms with non-material bad news might choose to disclose it voluntarily because the benefits of reducing market uncertainty outweigh the costs. By providing evidence on how the new regulatory requirements affect the capital market, our study points out an important implication of accounting policies and the standard-setting environment as well. We show that not only is the market reaction to bad news disclosure associated with the degree of changes in uncertainty, but also the market's prior knowledge about the news plays an important role in explaining the impact of change in uncertainty on market reactions.

The remainder of the paper is organized as follows. Section 2 provides a review of internal control provisions under the SOX. Testable hypotheses are developed in section 3. Section 4 presents the empirical results, and the final section provides a summary and conclusions. 


\section{Internal Control Provisions of the Sarbanes-Oxley Act}

The Securities and Exchange Commission (SEC) recently adopted rules, the Public Company Accounting Reform and Investor Protection Act of 2002 (i.e., the Sarbanes-Oxley Act, SOX), concerning management's report on its "internal controls over financial reporting" and certification of disclosure. Under the Act, public companies must develop new practices involving corporate governance and financial reporting. One of the most challenging aspects of SOX's requirements is a company's responsibility for internal controls, which requires public companies to report annually on their internal controls over financial reporting.

Section 404 of SOX, entitled, "Management Assessment of Internal Controls," stipulates that public companies must take responsibility for maintaining an effective internal control system and for reporting on the system's effectiveness. The rule is aimed at helping companies prevent financial reporting mistakes and fraud. Section 404 of SOX requires most publicly registered companies and their independent auditors to report on the effectiveness of the company's internal controls over financial reporting. After a company's managers review the internal controls, its external auditor must perform an independent assessment and report whether it agrees with management's conclusions on the review.

Meanwhile, Section 302 of SOX, Corporate Responsibility, requires the disclosure of internal control deficiencies. Management is required to state, in the Section 302 certification, that the CEO and CFO have evaluated the effectiveness of controls, have disclosed all significant deficiencies and material weaknesses to the auditors and audit committee, and have reported significant changes in the company's internal controls. After provisions of Section 302 become effective, but prior to the mandatory compliance date of Section $404,{ }^{6}$ firms publicly disclose internal control deficiencies on various SEC filing forms (e.g., 10-K, 10-Q, 8-K, proxy statements, etc.).

\footnotetext{
${ }^{6}$ Companies meeting the definition of "accelerated filers" (generally, firms with market capitalization over $\$ 75$ million) are required to comply with the new requirements for fiscal years ending on or after November 15, 2004. Small firms and foreign issuers are required to comply with the rules for their fiscal years ending on or after July 15, 2006, which is a one-year extension from the previously established July 15, 2005 compliance date. The compliance date for small firms is further extended to 2007.
} 
The Public Company Accounting Oversight Board (PCAOB, 1994, Paragraph 9 \& 10) defines different types of control deficiencies. A material weakness is "a significant deficiency, or a combination of significant deficiencies, that results in more than a remote likelihood that a material misstatement of the annual or interim financial statements will not be prevented or detected." A significant deficiency is defined as "a control deficiency, or combination of control deficiencies, that adversely affects the company's ability to initiate, authorize, record, process, or report external financial data reliably in accordance with generally accepted accounting principles such that there is more than a remote likelihood that a misstatement of the company's annual or interim financial statements that is more than

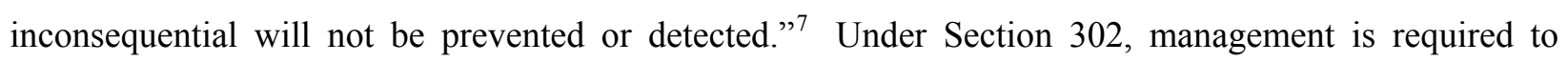
disclose such deficiencies to the auditors and audit committee but not to the public. Management is required to disclose all material weaknesses that exist as of the end of the most recent fiscal year, but minor deficiencies are not required to be publicly disclosed (see Auditing Standards No. 2, 2004). Also, Section 302 requires firms to disclose "significant changes in internal controls," and therefore known material weaknesses may not be disclosed. These discussions suggest that some types of disclosure under Section 302, especially those that are non-material weakness and/or known weakness, are voluntary.

\section{Hypothesis Development}

\section{Uncertainty and Returns around Disclosure of Internal Control Deficiencies}

The effect of the disclosure of internal control problems under Section 302 on a firm's value can be understood based on the dividend discount or cash-flow discount valuation model. According to the cash-flow discount model, a change in a firm's stock price may result from a change in future cash flows or a change in the discount rate. A primary goal of internal controls over financial reporting is to ensure the reliability of financial reporting in accordance with Generally Accepted Accounting Principles (GAAP). Less-effective internal controls will harm the accounting procedures' reliability and

\footnotetext{
${ }^{7}$ The term "remote likelihood" as used in the definitions of significant deficiency and material weakness (paragraph 10) has the same meaning as the term "remote" as used in Financial Accounting Standards Board Statement No. 5, Accounting for Contingencies ("FAS No. 5").
} 
effectiveness, thereby causing greater costs. Also, firms experiencing internal control problems must spend time and resources to fix them. Consequently, internal control problems would affect a firm's future cash flows negatively.

It is less clear how the ICDs affect the discount rate. The discount rate is directly related to the level of uncertainty about firm value. Disclosing internal control problems may increase uncertainty about a firm's reporting quality when investors did not expect such problems previously, or when disclosed problems are more severe than expected. Internal control problems reduce investor confidence as well. Investors are less likely to trust previously disclosed earnings numbers and any management earnings forecasts when firms with less-effective internal controls release such information. Conversely, a release of new information may reduce information asymmetry, which contributes to uncertainty about firm value, and therefore reduce the cost of capital. Healy and Palepu (1993) argue that corporate managers' disclosure strategies provide important means for imparting their knowledge to outside investors. This indicates that disclosure can help investors understand managers' private information and business strategies.

Easley and O'Hara (2004) demonstrate, in their asymmetric information asset-pricing model, that the cost of capital is higher for stocks with greater private information because such information increases the risk to uninformed investors and, in equilibrium, investors require compensation for bearing this risk. A firm can influence its cost of capital by changing the precision and quantity of information available to investors. Easley and O'Hara (2004) show that shifting information from private to public decreases the cost of capital because public information reduces uninformed traders' risk of holding the stock.

Recently, Lambert et al. (2007) dispute Easley and O'Hara's (2004) claim that information quality represents a unique risk factor arising from information asymmetry. Lambert et al. (2007) suggest that cash flow variance is diversifiable as the economy becomes large. They argue that information quality can affect the cost of capital either directly through the conditional covariance of the firm's cash flow with the market or indirectly through agency problems. While Easley and O'Hara's model shows an information risk premium in a multi-asset rational expectation model, Lambert et al.'s model is based on 
the Capital Asset Pricing Model (CAPM) setting. Since the single-factor CAPM fails to explain other risk factors in the cross-section of expected returns (Fama and French, 1992), it is difficult to believe that any model based on the CAPM can explain other unspecified risk factors, including an information risk factor (Indjejikian, 2007). Moreover, in the Lambert et al.'s framework, one firm's disclosure affects not only its own cost of capital, but also other firms' cost of capital because of the covariance of cash flows considered in the model. This means that firms' disclosure decisions can be strategic. While an examination of the relation between strategic disclosure and cost of capital would be interesting, the primary focus of our study deals with the relation between the market reaction and the changes in uncertainty around ICDs. Therefore, we construct an uncertainty measure following Easley and O’Hara (2004).

While ICDs often increase uncertainty, ICDs also can reduce uncertainty about the firm's value. In this study, we assume that the market risk premium might be higher before a firm discloses its internal control weakness and then decreases after the ICD. That is because investors may have suspected the effectiveness of internal controls, but are uncertain about the seriousness of the problem prior to the ICD. In such cases, ICDs can resolve uncertainty.

Based on the discussions above, we argue that if disclosing internal control problems reduces (increases) uncertainty about firm value and therefore lowers (increases) the discount rate, market reactions to such disclosure will be less (more) negative. We posit the following hypothesis (in an alternative form):

H1: The disclosures of internal control weaknesses under Section 302 that decrease market uncertainty are associated with less negative abnormal stock returns.

\section{Uncertainty, Type of Disclosure, and Information Environments}

Changes in uncertainty around ICDs can be modeled as a function of the type of disclosure and information environment. Section 302 does not require a firm to publicly disclose its internal control 
deficiencies other than material weakness. Management is only required to disclose such deficiencies to the auditors and audit committee. In this sense, disclosing non-material deficiencies is voluntary in nature. Managers can choose to disclose internal control deficiencies to reduce or eliminate market uncertainty that is potentially costly, and to avoid the potential for these deficiencies to be recognized as material weaknesses. $^{8}$

Verrecchia (1983) proposes the existence of an interior, optimal level of disclosure involving a trade-off between the benefit of a lower cost of capital and the cost of revealing proprietary information. Even if disclosure is costly because of product market consequences, managers make disclosure decisions by trading-off these costs against the benefits of disclosure from mitigating information asymmetry. ${ }^{9}$ Prior empirical studies show a negative relation between the level of voluntary disclosure and a firm's cost of capital (Botosan 1997; Sengupta 1998; Botosan and Plumlee 2002). Based on the legal liability argument, Skinner $(1994,1997)$ finds that voluntary disclosure of bad news is motivated by the need to avoid and/or mitigate large stock price declines. That is, managers have incentives to preempt large, negative surprises by voluntarily disclosing bad news early. The risk of litigation and the cost of resolving it will be greater with large information asymmetry and volatile stock prices. As a result, the benefit of disclosing bad news early will be greater if it reduces information asymmetry and uncertainty. Therefore, we predict that voluntary disclosures of non-material internal control deficiencies under Section 302 are likely to reduce market uncertainty. ${ }^{10}$

\footnotetext{
${ }^{8}$ Hammersley et al. (2008) view that non-material weakness disclosures simply act as a proxy for the severity of the internal control weakness and thus would be considered as good news relative to a material weakness disclosure. In contrast, we treat non-material (material) weakness disclosures as voluntary (involuntary) disclosures. We believe that the voluntary nature of non-material weakness disclosure is more closely related to the changes in market uncertainty than its severity. However, we cannot completely rule out the possible effect of severity on the market reaction to uncertainty change.

${ }^{9}$ Dye (1985) proposes that investors are uncertain about the managers' private information and thus they cannot infer from silence that managers are withholding negative news. However, bad news will be disclosed when the costs of disclosure are low enough or when the uncertainty is high, thereby reducing the uncertainty, which benefits the firm greatly.

${ }^{10}$ While voluntary disclosure of non-material IC deficiencies is expected to decrease uncertainty, certain types of material weaknesses also can lead to a reduction of uncertainty. Material weakness is the most severe type of internal control weakness. Within the material weakness classification, the severity of internal control problems varies. For example, Moody's suggests that account-specific material weakness is "auditable" and thus does not
} 
Meanwhile, changes in market uncertainty around ICDs would depend on the market's prior knowledge of the credibility of the firms' financial reporting. The effect of ICDs on uncertainty may vary by the information environment around ICDs (i.e., the presence or absence of previously announced suspicious events). When there exist informational clues about financial reporting quality that signal potential problems with internal controls, voluntary disclosure of non-material internal control problems can reduce uncertainty.

Assume that there are three types of firms: 1) clean firms with no internal control deficiencies, 2) deficient firms, and 3) material weakness firms. Reliability of the internal control system and thus the financial reporting system would be highest for clean firms, second-highest for deficient firms, and lowest for material weakness firms. ${ }^{11}$ When there is no suspicious event prior to a voluntary ICD, investors may perceive that the population of potential voluntary disclosure firms is comprised of clean firms and deficient firms because material weakness should have been already disclosed in a timely manner. In such a case, the voluntary disclosure of a deficiency can only resolve uncertainty about whether the firm is a clean firm or a deficient firm. Deficiency disclosure therefore will increase the uncertainty about firm value. In this sense, the disclosing firm may bear costs from the voluntary disclosure of minor deficiencies when investors are surprised by negative news. However, managers also may incur reputational costs if they fail to disclose negative news in a timely manner (Skinner 1994, 1997).

Alternatively, investors may associate the average level of uncertainty with all types of firms prior to public disclosure of internal control problems. Since investors may not be sure about if and/or when internal control problem became material, they cannot safely rule out the possibility of material weakness. Within this information environment, when a firm voluntarily discloses its internal control weakness, uncertainty about firm value may increase (type 2 vs. 1) or decrease (type 2 vs. 3 ).

represent as a serious concern regarding the reliability of the financial statements. Recently, Doyle et al. (2007b) find that lower accruals quality is not driven by the disclosure of account-specific material weaknesses. Rather, they present evidence that accrual quality is associated with company-level material weaknesses. This indicates that while ICDs often appear to increase uncertainty regarding reporting quality, certain material-weakness disclosures may result in a decrease in uncertainty.

${ }^{11}$ We gratefully acknowledge insights from an anonymous referee who suggested this clarification in developing the hypothesized relations between internal control disclosure and market uncertainty. 
In contrast, if there exist prior suspicious events, investors already suspect the credibility of the financial reporting system, but do not know whether the emerging IC problem is material until the ICD (either voluntary or mandatory). In such a case, clean firms are already ruled out, and investors face the choice between deficient firms and material weakness firms. Under this circumstance, if a firm voluntarily communicates its (non-material) IC matters, the disclosure might result in a reduction in market uncertainty for the firm because investors view suspected IC problem as less serious than expected. Therefore, disclosure of non-material ICD can decrease uncertainty when there exist previous suspicious events. Taken together, this leads to the following hypotheses (in alternative forms):

H2a: The reduction in market uncertainty is more likely for voluntary disclosures of internal control deficiencies.

$\mathrm{H} 2 \mathrm{~b}$ : The reduction in market uncertainty is greater for voluntary disclosures of internal control deficiencies when the market has suspected the firm's internal control problem prior to public disclosure.

\section{Market Reactions to Changes in Uncertainty, Type of Disclosure, and Information Environments}

Given that firms are more likely to disclose when the benefits of disclosure exceed the costs, market reaction to an uncertainty decrease triggered by a voluntary ICD will be less negative (or more positive) because investors would perceive voluntary disclosure as good news. However, if the voluntary ICD does not reduce uncertainty but increases it, then the market punishment will be greater, as investors expecting a decrease in uncertainty from voluntary disclosure are disappointed with undesirable outcomes (e.g., uncertainty increasing disclosure). Both of the above scenarios imply that the impact of changes in uncertainty on abnormal returns is more pronounced for the voluntary disclosure of non-material internal control deficiencies.

Meanwhile, the relation between the change in uncertainty and returns around ICDs may vary depending on the market's prior knowledge of the credibility of the firm's financial reporting. Market 
participants' prior knowledge regarding the strength (or weakness) of a firm's financial reporting would have already been impounded in the stock price and reflected in the dispersion of investors' beliefs. Thus, investors can learn the "type" of ICD (i.e., material/ involuntary vs. non-material/voluntary) in the context of their prior beliefs, and relative to the "type" of information environment (i.e., the presence or absence of previously announced suspicious events). When the market has suspected a firm's internal control deficiency and thus questioned the reliability of financial reporting systems prior to public disclosure, the uncertainty-reduction effect of the ICD (i.e., less negative market reaction induced by a decrease in uncertainty) would be more pronounced for voluntary disclosure because the voluntarily disclosed control weakness is regarded as less serious (i.e., non-material). In contrast, if the voluntary disclosure unexpectedly increases uncertainty, then the market reaction will be even more negative because investors with prior knowledge of a firm's suspicious events may expect an uncertainty-clearing disclosure from voluntary ICDs. Together, these two effects will make market reaction to changes in uncertainty more pronounced.

Therefore, we predict that the impact of changes in uncertainty on abnormal returns would be more pronounced for the voluntary disclosure of non-material internal control deficiencies, and such a relation would be even more pronounced when the market has suspected the firm's internal control deficiency prior to public disclosure. We present the following two hypotheses (in alternative forms):

H3a: The negative association between abnormal stock returns and changes in market uncertainty is more pronounced for voluntary disclosure of non-material internal control weakness.

$\mathrm{H} 3 \mathrm{~b}$ : The negative association between abnormal stock returns and changes in market uncertainty is more pronounced for voluntary disclosure of non-material internal control weakness when the market has suspected the firm's internal control problems prior to public disclosure. 
Figure 1 depicts the above hypotheses. ${ }^{12}$ In Figure 1 , the ovals are factors that moderate the relations between disclosures of internal control weaknesses, market uncertainty, and abnormal stock returns. On the horizontal level, a disclosure of internal control deficiencies results in a decrease or an increase in market uncertainty, and thereby affects the stock returns around the disclosure. Figure 1 also shows the vertical impact of the disclosure environment on market returns. The type of the disclosure and the market's prior knowledge of the effectiveness of the firm's financial reporting together can play a role in changing the market uncertainty around the disclosure, which in turn affects the stock return. Our H1 highlights the horizontal relationships and $\mathrm{H} 2 \mathrm{a}$ and $\mathrm{H} 2 \mathrm{~b}$ focus on the vertical impact of voluntary disclosure and the market's prior knowledge on uncertainty, while H3a and H3b portray the combined effect.

\section{Empirical Results}

\subsection{Sample Characteristics and the Stock Market Reactions to Disclosure}

The sample of 608 disclosures of internal control problems in 2004 is obtained from the Internal Control Disclosure database of ComplianceWeek. In the ComplianceWeek database, some firms have multiple disclosures for the same internal control deficiencies. We include the first disclosure of each weakness for each of these firms. Stock returns are obtained from the Center for Research in Security Prices (CRSP) database, and earnings announcement dates, accounting variables, and auditor variable are obtained from the COMPUSTAT database. We eliminate 214 disclosures because of duplicates and missing returns in the CRSP database for the three-day window (day -1 to +1 ) around the dates of disclosure. The final sample contains 394 disclosures. Actual samples used in the analyses are slightly different because of the availability of other variables. To take a closer look at the distribution of ICDs, Figure 2 plots the frequencies of ICDs by month during 2004. As shown, the highest number of

\footnotetext{
${ }^{12}$ We gratefully acknowledge insights from an anonymous referee, who suggested the figure to represent the hypothesized relations among internal control disclosure, market uncertainty, and abnormal returns around disclosure.
} 
disclosures is made in November. We also find that the tendency to disclose significantly increases in the second half of $2004 .^{13}$

Table 1 presents descriptive statistics of key variables. $C A R_{-1,1}$ is the market-adjusted, cumulative, abnormal returns over a three-day window surrounding the announcement of internal control problems, where market return is the return on the CRSP value-weighted index. In Panel A, the mean and median of $C A R_{-1,1}$ are -0.0132 and -0.0051 , respectively. The mean and median are statistically significant at the one-percent level, indicating that investors in the market generally consider internal control problems as a negative development. In panel B, STD is the standard deviation of daily stock returns over the 120 trading days prior to disclosure (day -121 to -2). $S T D_{a f}$ is the standard deviation of daily stock returns over the 120 trading days after disclosure (day +2 to +121 ). CSTD is the change in the standard deviation of daily stock returns, measured as $S T D_{a f}-S T D$. The mean (median) value of CSTD is $-0.0010(-0.0027)$, indicating that, on average, the return volatility is reduced after a disclosure of internal control problems. ${ }^{14} \mathrm{We}$ compare the standard deviation prior to and after disclosure of internal control deficiency for each firm using the Folded F-test of homogeneity of variance. The average significance of the firm-specific changes in standard deviations before and after disclosure is 0.2031 , while the median is 0.0358. ${ }^{15}$ The Folded-F-test shows a larger number of significant negative changes in STD than significant positive changes in our sample firms.

Panel C of Table 1 presents the distribution of ICDs by industry. During 2004, approximately one-third of the disclosures (135 out of 394) are made by two industries: computer equipment and services, and electronic equipment (two-digit SIC codes 35, 73, and 36). Those are followed by financial institutions, which report 37 disclosures.

\footnotetext{
${ }^{13}$ Section 404 is effective for larger firms for fiscal years ending on or after November 15, 2004. The first set of Section 404 disclosures is made early February 2005. To avoid a potential Section 404 effect, we run the tests with the standard deviation of daily stock returns over the shorter period of time (e.g., over 3 days $\sim 60$ days) and obtain qualitatively the same results.

${ }^{14}$ Of the 394 disclosures, 247 result in decreases in stock-return volatility, whereas 147 result in increases in stockreturn volatility.

${ }^{15} \mathrm{We}$ also run the Folded F-test only with firms whose stock returns are available for all of 120 days before and after the ICD and obtain the results similar to those tabulated in Panel B of Table 1 and Panel D of Table 2.
} 
Table 2 presents the univariate test results. In this study, we use the standard deviation of daily stock returns to capture market uncertainty about firm value. Prior studies (e.g., Sengupta, 1998; Zhang, 2006) use the standard deviation of stock returns as a proxy for uncertainty. Analysts' forecast dispersion is another proxy for uncertainty used in the prior literature. However, Barron, Kim, Lim, and Stevens (1998) show that forecast dispersion equals one minus the commonality among different analysts' beliefs times uncertainty. Following this model, Barron, Byard, and Kim (2002) warn that using forecast dispersion as a proxy for commonality alone or for uncertainty alone may lead to erroneous interpretation of empirical evidence. ${ }^{16}$

Panel A of Table 2 presents $C A R_{-1,1}$ by change in the standard deviation of stock returns. About 63 percent ( 37 percent) of the entire disclosures results in a decrease (an increase) in stock-return volatility. The mean value of $C A R_{-1,1}$ for volatility-decreasing disclosures (-0.0039) is much higher than that for volatilityincreasing disclosures (-0.0290). Abnormal returns are significantly negative only for volatility-increasing disclosures. The difference in the market reactions between the two groups is statistically significant at the one-percent level based on the t-test and the Wilcoxon two-sample test. The result shown in Panel A is consistent with $\mathrm{H} 1$.

Panel B shows the market reactions to five types of disclosure. ComplianceWeek classifies firms' disclosure of internal controls into seven areas. We regroup the ComplianceWeek categorizations into five types, by grouping "lack of internal controls," "potential problems," and "allegations" together because we have only 13 total observations of these types of disclosure. The Appendix shows examples of five types of disclosure for internal control problems. Disclosure of material weaknesses accounts for 57.6 percent of the entire sample of disclosures. The mean and median values of $C A R_{-1,1}$ are negative and significant ( $\mathrm{p}$-values $=0.0013$ for the t-test and 0.0015 for the Wilcoxon test) for this type of disclosure.

\footnotetext{
${ }^{16}$ To examine whether our results are robust to an alternative proxy for market uncertainty, we re-estimate the regression equations using the analysts' forecast dispersion as an alternative proxy for uncertainty. We measure the changes in analyst forecast dispersions as the difference between the forecast dispersions for the last earnings per share (EPS) forecast prior to the disclosure and those for the first EPS forecast 45 days after the disclosure. The results are discussed in the sensitivity analysis section later.
} 
Abnormal returns are statistically insignificant or only marginally significant for other types of disclosure; however, the statistical insignificance may just reflect the small number of observations.

Panel C of Table 2 reports a two-by-two analysis of $C A R_{-1,1}$ : by the type of disclosure of internal control weaknesses and the change in the standard deviation of stock returns (CSTD). As shown, for disclosure of both material weakness and other weakness, the mean values of $C A R_{-1,1}$ are higher (lower) when the standard deviation of stock returns decreases (increases). For disclosure other than material weakness, the difference in the mean values of $C A R_{-1,1}$ between the two groups (e.g., firms with a decrease or an increase in the standard deviation) is statistically significant at the one percent level based on a t-test and a Wilcoxon test ( $\mathrm{p}$-values $=0.0022$ for the $\mathrm{t}$-test and 0.0005 for the Wilcoxon test). Market reactions to the disclosure of material weakness and other type of weaknesses differ when ICD reduces the standard deviation of stock returns ( $\mathrm{p}$-values $=0.0235$ for the $\mathrm{t}$-test and 0.0182 for the Wilcoxon test). However, this is not the case when market uncertainty increases after the internal control problem is disclosed. A decrease (increase) in the CSTD might indicate that the market already suspected (did not suspect) the ICD. For example, when the CSTD decreases, the near-zero returns for the 'Others' / 'Decrease' group (0.0056) are consistent with the market not being surprised by the disclosure, while the significantly negative returns for the 'Material Weakness' / 'Decrease' group (-0.0122) support the market being surprised by the material nature of the internal control weakness. When the CSTD increases (i.e., the market did not suspect the ICD), the market is surprised by both types of disclosure. The above speculations are more formerly tested in Panel D.

While Panels $\mathrm{A}, \mathrm{B}$, and $\mathrm{C}$ of Table 2 show the relations between $C A R_{-1,1}$ and changes in the standard deviation of returns and/or disclosure types, Panel D and reports the changes in standard deviation of returns and $C A R_{-1,1}$ by the type of disclosure and the firm's information environment (e.g., prior suspicious events). We conjecture that changes in market uncertainty around the disclosure of internal control weaknesses may vary depending on the market's prior knowledge of the credibility of the firms' financial reporting and other managerial issues at the firm. We measure the market's prior knowledge with the incidence of prior events that might give the market a clue about the firm's internal control 
deficiency. Events that occurred during the six months prior to the ICD are identified through a search on the Factiva database. The types of prior events searched include earnings restatements, management changes, auditor changes, delayed filing, SEC investigations, internal control issues, and other accounting problems. To gain quick insight into how the types of disclosure and the information environment affect market uncertainty and returns, we perform a two-by-two analysis based on the types of disclosure and the incidence of prior suspicious events.

When the market has prior knowledge of suspicious events, uncertainty decreases for the 'Others' group around ICDs, consistent with uncertainty reduction for the 'Others' group but not for the 'Material Weakness' group. While the results are similar when there's no suspicious event prior to the ICD, the standard deviation of returns decreases most for firms disclosing non-material internal control deficiencies voluntarily when prior suspicious events exist. The mean (median) value of CSTD for these firms is $-0.0058(-0.0055)$. The Folded F-test of homogeneity of variance shows that the mean (median) significance of the firm-specific changes in standard deviations before and after disclosure is 0.0287 (0.0197). When the prior suspicious events exist, the proportion of the number of significant decrease in uncertainty (i.e., CSTD $<0)$ is higher for voluntary disclosures of non-material weaknesses (14 out of 27) than for the disclosure of material weaknesses (14 out of 55). In sum, these results suggest that when the market has prior knowledge of the financial reporting and other managerial issues at a firm, the firm's voluntary disclosure of non-material internal control deficiencies reduces market uncertainty.

As shown on the bottom half of Panel D of Table 2, when the market has prior knowledge of suspicious events, market reactions to the disclosure of material weakness are negative, while those to the disclosure of less severe weakness are not. Under the existence of prior suspicious events, material weakness ICDs experience negative CAR but voluntary ICDs result in positive CAR around ICDs (i.e., mean value of CAR for material weakness ICDs $=-0.0249$, and that for other voluntary ICDs $=0.0130$ ). The differences in mean and median values of CAR between material weakness and non-material weakness groups are significant at the 10 percent levels. However, when there's no suspicious event prior to the disclosure, the difference in market reaction is not statistically significant between two types of ICDs. 
This suggests that with the presence of prior suspicious events, voluntary disclosure of non-material deficiencies reduces uncertainty, thereby leading to a positive market reaction, which is consistent with the result reported in Panel C.

\subsection{Market Reaction to ICD and Changes in Uncertainty}

To examine the market reaction to the disclosure of internal control problems conditional on changes in market uncertainty after controlling other factors affecting firm returns, we estimate the following regression equation:

$$
C A R=a 0+a 1 \text { CSTD }+a 2 S T D+\sum_{i=1}^{n} \gamma_{i} \text { Control Variables }_{i}
$$

where $C A R_{-1,1}$ is market-adjusted, cumulative, abnormal returns over a 3 -day window (day -1 to +1 ) surrounding the announcement of internal control problems, where market return is the return on the CRSP value-weighted index; CSTD is the change in the standard deviation of daily stock returns, measured as $S T D_{a f}-S T D$, where $S T D_{a f}$ is the standard deviation of daily stock returns over 120 days $(+2$ to +121 ) after the disclosure; $S T D$ is the standard deviation of daily stock returns over 120 days (day -121 to -2$)$ prior to the $\mathrm{ICD}^{17}$. In this study, we use the change in the standard deviation of daily stock returns, CSTD, as a proxy for the change in market uncertainty. We add the level of the standard deviation of daily stock returns over the prior 120 days to the models because the market reaction to ICDs may depend on the level of uncertainty as well as the change.

Hammersley et al. (2008) provide evidence that the market returns are influences by the management's evaluation on the effectiveness of internal control, auditability of an internal control weakness, vagueness of the disclosure, and auditor discovery. To control for the effect of those

\footnotetext{
${ }^{17} \mathrm{We}$ also calculate the change in and the level of the return standard deviation over a shorter window around the internal control disclosure as alternative measures. Details are discussed in subsection 4.7.
} 
characteristics of ICDs, we include these four disclosure attributes: EFFECTIVE, ACCT_SPECIFIC, VAGUE, and AUDIT_IDENTD (See Appendix II for variable definitions). ${ }^{18}$

We also include several other control variables suggested by the previous studies. Prior research documents that firm size and leverage are related to the market reactions to disclosure (Palmrose, Richardson, and Scholz, 2004; Bhojraj, Blacconiere, and D’Souza, 2004; Collins, Kothari, and Rayburn, 1987). Thus, we add two control variables, $L O G \_S I Z E$ and LEVERAGE, to the regression model. The negative market reaction to ICD will be less severe for larger firms because the market already incorporates information through other sources, while the greater risk associated with leverage will make the negative market reaction stronger. Accordingly, a positive (negative) coefficient on LOG_SIZE (LEVERAGE) is predicted. We add book-to-market equity and beta to control for other Fama and French (1993) factors.

Following Palmrose et al. (2004), who examine market reactions to restatements, we include the stock return over the prior 120 days as an additional control variable. Stock returns prior to the disclosure can make market reactions either stronger or weaker. If the negative stock returns prior to the disclosure reflect information leakage related to internal control problems, the market reaction at the time of the disclosure will be weaker. However, if the negative returns reflect other negative developments for the firm, the negative market reaction at the time of the disclosure will be even stronger. $R E T$ is an indicator variable that equals one if the buy-and-hold market adjusted returns over the prior 120 days (-121 to -2$)$ is less than zero, and zero otherwise. The $A C C E L$ variable also is included to capture the difference between accelerated filers and other firms. Accelerated filers are required to comply with the Section 404 requirements for fiscal years ending on or after November 15, 2004. Small firms are allowed to comply with the rules much later. If a firm is an accelerated filer and discloses its internal control problems, then the market reaction to disclosure might be less negative because the firm is facing mandatory compliance with the new rules in the near future and the disclosure signals that the firm can identify the internal control deficiencies early and therefore is ready to fix the problems before the Section 404 compliance date. Thus, we predict the sign of the coefficient on

\footnotetext{
${ }^{18}$ We use $A C C T$ SPECIFIC, an indicator variable that equals one if the internal control weakness is related to any specific balance sheet/income statement account (generally considered as auditable in the prior literature), as a proxy for the auditability.
} 
$A C C E L$ will be positive. Finally, investors may respond to the same disclosure differently only because the auditor quality is different. Prior literature (Titman and Trueman, 1986; Nichols and Smith, 1983) documents that auditor quality affects market response and firm value. Willenborg (1999) finds that auditor choice affects the cost of capital (e.g., IPO underpricing). Thus, we add an auditor dummy variable, $N O N B 4$, to control for the effect of auditor quality. We expect that information disclosure made by firms with low-quality auditors will bring more negative market reaction. Thus the sign of the coefficient on NONB4 is predicted to be negative.

Prior research has also identified determinants of material weaknesses in internal control. These determinants are potentially associated with market reactions as well. Firms with internal control weaknesses tend to be less profitable, smaller, younger, more complex, growing rapidly, or undergoing restructuring (e.g., Ge and McVay 2005; Ashbaugh-Skaife et al. 2006; Doyle, et al. 2007a). To control for the effects of those variables, we include the following variables in our regressions: the complexity of the firm's operations (LOG_GOSEG); the existence of a foreign currency translation (FOREIGN); restructurings (RESTRUCT); sales growth (SALEGRW); inventory ratio (INVNTRY); profitability (Loss); Altman's Z-Score (RZSCORE); the age of the firm $\left(L O G_{-} A G E\right)$; incidence of a merger or acquisition (M\&A). To control a potential industry effect, industry dummy variables are also included in most regressions. All variables are defined in Appendix II.

H1 predicts that if ICD reduces market uncertainty, then the market reaction to a firm's disclosure of internal control deficiencies will be less negative. Table 3 reports the results of the estimation of Equation (1). To gain quick insight, we run the first regression model with only one control variable, STD. The coefficient on the variable of interest, CSTD, is negative and statistically significant (t-value $=-2.43$ ). We interpret this result to mean that firms that disclose their internal control weaknesses experience less negative declines in stock prices when their disclosure contributes to a reduction of market uncertainty (e.g., a decrease in the standard deviation of stock returns after the disclosure). STD is also negatively associated with $C A R_{-1,1}$. The negative coefficient on $S T D$ is consistent with the uncertainty discount; investors further discount the stock prices of firms with greater uncertainty. 
The second regression model includes other disclosure and firm attributes as control variables. The coefficients on control variables for firm attributes and industry dummies are not reported for brevity. ${ }^{19}$ CSTD still shows a significant and negative relation to stock returns ( $\mathrm{t}$-value $=-3.11)$, even after controlling for other plausible explanatory variables, including industry dummies. Consistent with Hammersley et al. (2008), the coefficient on $V A G U E$ is negative and statistically significant, indicating that if disclosed internal control weaknesses are vague, then the stock market reacts more negatively to the disclosure. Collectively, the results suggest that the market response to a firm's disclosure of internal control problems is less negative when the disclosure reduces uncertainty in the market. This result supports H1.

We also run regression equation (1) with an indicator variable for the change in the standard deviation of daily stock returns, rather than a continuous variable. The indicator variable takes one if the standard deviation increases after the internal control deficiency disclosure, and zero otherwise. The untabulated evidence shows qualitatively the same results. The coefficient on the indicator variable is negative and statistically significant at the five-percent level. Thus, using an indicator variable does not alter the negative relation between $C A R_{-1,1}$ and the change in uncertainty.

\subsection{Changes in Market Uncertainty across Types of Disclosure and Information Environments}

To test $\mathrm{H} 2 \mathrm{a}$ and $\mathrm{H} 2 \mathrm{~b}$, we estimate the following cross-sectional model ${ }^{20}$ :

$C S T D=a 0+a 1 S T D+a 2 D \_V O L+a 3$ D_SUS $+a 4 D_{-}$VOL ${ }^{*} \__{-} S U S+\sum_{i=1}^{n} \gamma_{i}$ Control Variables $i$

where CSTD is the change in the standard deviation of daily stock returns; STD is the standard deviation of daily stock returns over 120 days (day -121 to -2 ) prior to the ICD; $D \_V O L$ is an indicator variable that equals one if the type of ICD is non-material weakness, and zero otherwise; $D \_S U S$ is an indicator

\footnotetext{
${ }^{19}$ The coefficient on LEVERAGE is negative but marginally significant only occasionally. Restructuring firms tend to experience more negative market reactions at the time of internal control deficiency disclosure. Other firm attributes are insignificant.

${ }^{20} \mathrm{We}$ are grateful to an anonymous referee who suggested this model to test changes in uncertainty as a function of the information environment and the attributes of the disclosures.
} 
variable that equals one if an ICD follows events (such as earnings restatements, management changes, accounting problems) that might give the market a clue about the firm's financial reporting problems during the six months prior to the internal control disclosure. Prior events are identified through a search on the Factiva database; and control variables are the same as defined in Appendix II.

Table 4 presents the results. From model 1 of Table 4, it is evident that before controlling for other disclosure and firm attributes, voluntary disclosure of non-material internal control weaknesses contributes to a reduction of uncertainty. The coefficient on $D_{-} V O L$ is negative and significant ( $\mathrm{t}$-value $=$ -2.31) at the five-percent level. D_VOL shows a negative, significant relation with CSTD even after controlling for other disclosure and firm attributes. These results support H2a. To test H2b, we conduct two difference tests. We compare CSTD of voluntary disclosures versus material weakness disclosures in the context of prior suspicious events to examine the marginal effect of voluntary disclosure. We also compare CSTD of voluntary disclosures with versus without suspicious events to examine the marginal effect of suspicious events. As predicted in $\mathrm{H} 2 \mathrm{~b}$, when the market has already known a firm's financial reporting problem through prior suspicious events and the firm voluntarily announces its internal control problems that are less severe, the combined effect tends to reduce uncertainty. The coefficient on $D_{-} V O L^{*} D \_S U S$ is negatively significant $(\mathrm{t}-\mathrm{value}=-2.15$ ). The coefficients on the control variables for firm attributes and industry dummies are not reported for brevity. As shown in model 4 of Table 4, this result remains unchanged even after controlling for other disclosure and firm attributes.

Significance tests of the marginal effect of voluntary disclosure and of prior suspicious events are reported in the bottom rows of Table 4 . The results show that the marginal effects of voluntary disclosure in the context of prior suspicious events are statistically significant at the five-percent level in models 3 and 4. Similarly, the marginal effects of prior suspicious events in the case of voluntary disclosure are significant in both models. 
In summary, the results regarding the change in uncertainty around ICDs suggest that voluntary disclosure of weak internal control problems contributes to a reduction in uncertainty and this effect is more pronounced when the market has prior knowledge of the financial reporting problems.

\subsection{Market Reaction to ICD across Types of Disclosures}

To capture the net effect of voluntary disclosure on the stock returns $(\mathrm{H} 3 \mathrm{a})$, we include $D_{-} V O L$ and two interaction terms, $D_{-} V O L^{*} C S T D$, and $D_{-} V O L^{*} S T D$, in the regression equation (1), where $D_{-} V O L$ is an indicator variable that equals one if the type of ICD is non-material weakness, and zero otherwise. $^{21}$

$$
\begin{aligned}
C A R= & a 0+a 1 C S T D+a 2 S T D+a 3 D_{-} V O L+a 4 D_{-} V O L * C S T D+a 5 D_{-} V O L * S T D \\
& +\sum_{i=1}^{n} \gamma_{i} \text { Control Variables }_{i}
\end{aligned}
$$

Table 5 presents the results. In model 1 , the coefficients on $D_{-} V O L^{*} C S T D$ are negative and significant at the one percent level (t-values $=-3.57$ ). This suggests that the impact of changes in uncertainty on market reaction to disclosure is more pronounced for voluntary disclosure of non-material internal control deficiencies. For the disclosure of material weakness, CSTD shows a negative but insignificant relation to $C A R$. The coefficients on $D_{-} V O L^{*} S T D$ is positive and significant at the five percent level. The positive coefficient on $D_{-} V O L^{*} S T D$ indicates that firms with greater standard deviations of stock returns have more to gain from voluntary disclosure. That is, they have relatively higher abnormal stock returns around disclosures of internal control deficiencies relative to firms with lower standard deviations of stock returns. Together, evidence presented in model 1 supports our $H 3 a$, indicating that when the disclosures are voluntary in nature, the negative relationship between CSTD and $C A R$ appears more pronounced.

\footnotetext{
${ }^{21}$ We include $D \_V O L$ to capture the main effect of voluntary disclosure. $D \_V O L$ is also included to control for potential cash flow effect of voluntary disclosure since the market value of the firm is a function of cash flows and firm-specific cost of risk.
} 


\subsection{Market Reactions under Different Information Environments}

In $H 3 b$, we hypothesize that the relation between changes in uncertainty and market reaction also depends on the market's prior knowledge of the credibility of the firms' financial reporting. When the market has suspected the effectiveness of a firm's financial reporting and the firm voluntarily discloses non-material internal control deficiencies, then resolving the uncertainty would be more beneficial to the firm.

To capture the effect of voluntary disclosure of internal control deficiencies under different information environment, we include $D \_I N F O$ and two interaction terms, D_INFO*CSTD and D_INFO $* S T D$, where $D \_I N F O$ is an indicator variable that equals one if a firm voluntarily releases its internal control weaknesses when prior suspicious events of the firm are known in the market, and zero otherwise.

$$
\begin{aligned}
C A R= & a 0+a 1 \text { CSTD }+ \text { a2 STD }+ \text { a3 D_INFO }+a 4 D_{-} I N F O * C S T D+a 5 D_{-} I N F O * S T D \\
& +\sum_{i=1}^{n} \gamma_{i} \text { Control Variables }_{i}
\end{aligned}
$$

Model 2 in Table 5 reports the results. The coefficients on $D_{-} I N F O^{*} C S T D$ are negative and statistically significant ( $\mathrm{t}$-values $=-2.36$ ) at the five percent level. This indicates that if the internal control deficiency is voluntarily disclosed when prior suspicious events exist, the benefit of the decrease in uncertainty is greater, thereby making the negative relation between changes in uncertainty and abnormal returns more pronounced. That is, voluntary disclosures made in the context of previous suspicious events that reduce market uncertainty are likely to be considered 'less negative or even good news' and causes less negative CARs. This evidence is consistent with $H 3 b$. On the other hand, the coefficients on $D \_I N F O * S T D$ are positive but insignificant in model 2.

\subsection{Further Tests after Controlling for Earnings Announcements and Other Confounding Events around ICD}


Some internal control deficiencies are disclosed concurrently with quarterly or annual earnings announcements. In these cases, the market reactions to ICDs also may contain reactions to known information events, such as earnings releases. ICD may be accompanied by a number of other news events as well. Thus, we go on to control for all major confounding news events, including quarterly or annual earnings announcements, around the ICD. Confounding news events are identified through a search of publications by company name on the Factiva database. These events include earnings announcements, $10-\mathrm{K}$ or $10-\mathrm{Q}$ filing, dividend changes, stock repurchases, restructuring, security offerings, mergers and acquisitions, spin-offs, large layoffs, SEC allegations, earnings restatements, management changes, auditor changes, and conference calls.

To capture the net effect of ICD on the market after eliminating all other confounding effects, we employ two additional dummy variables, $D_{-} E A$ and $D_{-} E V E N T$. $D_{-} E A$ equals one if a firm announces its quarterly or annual earnings over the nine-day interval beginning (ending) four days before (after) the date of each ICD. D_EVENT equals one if a firm releases any confounding news events over the nine-day interval beginning (ending) four days before (after) the date of each ICD, zero otherwise. To control the effects of earnings announcements, $D \_E A$ as well as two interaction terms, $D_{-} E A * C S T D$ and $D \_E A * S T D$, are added to regression equations. Similarly, in order to control for other confounding events around ICDs, $D \_E V E N T, D \_E V E N T * C S T D$, and $D_{-} E V E N T * S T D$ are included in regression analyses.

Models 3 and 4 of Table 5 show the results after controlling for earnings announcements. The coefficients on both $D_{-} V O L^{*} C S T D$ and $D_{-} I N F O^{*} C S T D$ are negative and significant (t-values $=-2.02$ and -2.56 , respectively), even after controlling for the effect of earnings announcements. In both regressions, the coefficients on CSTD remain negative and significant. Models 5 and 6 of Table 5 report the results after controlling for all confounding events around the ICD. The coefficients on $D_{-} V O L^{*} C S T D$ and $D_{-} I N F O^{*} C S T D$ are also negative and statistically significant (t-values $=-2.80$ and -2.56 , respectively). These results are consistent with those reported in models 1 and 2 of the same table. 
Thus, controlling for the confounding effects does not alter our results in any meaningful way. These results are consistent with our hypotheses $\mathrm{H} 3 \mathrm{a}$ and $\mathrm{H} 3 \mathrm{~b}$.

\subsection{Simultaneous Equation Models of Changes in Uncertainty and Abnormal Returns around ICD}

So far, our tests are based on the assumption that certain disclosures of internal control deficiencies reduce market uncertainty, which in turn cause less negative stock returns. However, stock returns around the disclosure can affect the firm's disclosure decisions on internal control weaknesses, and thereby leading to a decrease or an increase in market uncertainty. That is, some other factors may cause a decline in the standard deviation and a less negative return. Hence, we utilize a different research design to address possible simultaneity problem and the reverse causality that may run from disclosure of weakness to changes in market uncertainty. ${ }^{22}$ In this framework we view both CAR and CSTD as related dependent variables that vary with the proxies for prior levels of information uncertainty and disclosure and firm attributes. The following simultaneous equation system is estimated:

$$
\begin{aligned}
C A R= & a 0+a 1 \text { CSTD }+a 2 S T D+a 3 D_{-} \text {VOL }(\text { or D_INFO })+a 4 D_{-} E A(\text { or D_EVENT }) \\
& +\sum_{i=1}^{n_{i}} \gamma_{i} \text { Control Variables }_{i} \\
C S T D= & b 0+b 1 \text { CAR }+b 2 S T D+b 3 D_{-} \text {VOL }(\text { or D_INFO })+b 4 D_{-} E A(\text { or D_EVENT }) \\
& +\sum_{j=1}^{n_{j}} \delta_{j} \text { Control Variables } j
\end{aligned}
$$

All variables are defined in Appendix II. To control for the potential effect of litigation risk on uncertainty changes, we include an indicator variable for high-litigation industry in the CSTD equations. We also include firm attributes, except book-to-market equity and beta, as well as industry dummies in the CSTD equations.

Table 6 reports the results. Again, the coefficients on control variables for firm attributes and industry dummies are not reported for brevity. In all CAR equations, the coefficients on CSTDs are negative and significant at the one percent level ( $\mathrm{t}$-value $=-2.88,-2.87,-3.12,-3.12,-2.90$, and -2.88 , respectively).

\footnotetext{
${ }^{22}$ We gratefully acknowledge the suggestion from an anonymous referee for the research design that address the problem of simultaneity with changes in market uncertainty and abnormal returns around disclosures.
} 
$S T D$ also shows at least marginally significant negative relations to $C A R$ in all $C A R$ equations. These results are consistent with those reported in the previous tables. Meanwhile, in all CSTD equations, the coefficients on CARs are negative but insignificant. This indicates that stock returns around the ICDs do not significantly contribute to the change in market uncertainty. In sum, the evidence presented in Table 6 suggests that the negative impact of changes in uncertainty on market reactions is intact even after considering the simultaneity. However, the impact of voluntary disclosure and information environment on changes in uncertainty become insignificant when simultaneity is controlled.

\subsection{Sensitivity Analysis}

We conduct additional tests to evaluate the sensitivity of our results to alternative measures of market uncertainty. We employ the level of and change in analysts' forecast dispersion as alternative proxies for the level of and changes in market uncertainty. We measure analysts' forecast dispersion, $D S P$, as the standard deviation of analysts' annual earnings-per-share (EPS) forecasts in the last Institutional Brokers' Estimate System (IBES) statistical period prior to the internal control deficiency disclosure. The change in analysts' forecast dispersion, $\triangle D S P$, is the difference between the standard deviation of analysts' annual EPS forecasts in the first IBES statistical period 45 days after the internal control deficiency disclosure and that in the last IBES statistical period before the disclosure. Untabulated results show that the analyses using financial analysts' earnings forecasts dispersion as an alternative proxy for uncertainty do not alter the findings reported earlier.

We also conduct several tests with alternative measures of $C A R$ and the standard deviation of returns. While using a longer window to calculate the level of and changes in the standard deviation of returns reduces the measurement error stemming from thinly traded stocks and provides more stable measures, it also introduces other types of measurement error resulting from more confounding events during this longer window. We employ the levels of and changes in the standard deviation of returns calculated over shorter windows, 3-, 30-, and 60-day windows, instead of a 120-day window, and 
replicate the analyses. ${ }^{23}$ Untabulated results are qualitatively the same as those reported in the paper. Using other alternative measures, such as size-adjusted returns instead of market-adjusted returns and the abnormal change in standard deviation (i.e., market-adjusted changes in standard deviation) as a proxy for uncertainty, calculated by subtracting the standard deviation of market returns from the standard deviation of returns for an individual firm, does not change the results.

\section{Summary and Conclusions}

This study examines stock market responses to the disclosure of internal control deficiencies under Section 302 of the Sarbanes-Oxley Act. Recent literature (Ashbaugh-Skaife et al. 2008; Beneish et al. 2008; Ogneva et al. 2007) documents the relation between the cost of equity capital and ICDs. In this study, we focus on changes in market uncertainty as an important factor that contributes to the relation between the cost of capital and ICDs. Hammersley et al. (2008) present evidence that the stock price reaction to ICDs is influenced by such factors as management's evaluation of the effectiveness of internal control, auditability of an internal control weakness, vagueness of the disclosure, and auditor discovery. Although closely related, our study differs from Hammersley et al. (2008). By considering the effect of ICDs on market uncertainty, our study examines the impact of changes in market uncertainty on the cross-sectional difference in market reactions to ICDs. In this study, we argue that market reactions to firms' disclosure of internal control weaknesses are inversely related to the changes in uncertainty caused by the disclosure. We also argue that the negative relation between market reactions and changes in uncertainty is more pronounced for voluntary disclosures made in the context of previous suspicious events because they both reduce market uncertainty and cause less negative CARs.

We find that when a firm discloses its internal control deficiencies, its abnormal stock returns are negatively associated with changes in the standard deviation of daily stock returns. This suggests that when the disclosure of internal control deficiencies reduces uncertainty in the market, it has a less

\footnotetext{
${ }^{23}$ In addition, to see whether a decrease in uncertainty is caused by remedial actions taking place after disclosure of the deficiency, we conduct additional sensitivity analyses after excluding ICDs related to remedial actions. Untabulated results show that excluding these ICDs does not alter our main results.
} 
negative impact on stock prices. Consistent with our hypothesis, we also find that under Section 302, voluntary disclosures made in the context of previous suspicious events tend to reduce uncertainty. Furthermore, our evidence shows that the negative relation between changes in the standard deviation of stock returns and abnormal returns is more pronounced when a firm voluntarily discloses its non-material internal control deficiencies, and when there exist any clues regarding financial reporting problems prior to public disclosure.

These results are robust even after controlling for confounding events, including earnings announcements, around ICDs. It seems that not only is the market reaction to internal control deficiency disclosure associated with the degree of changes in uncertainty, but also the disclosure attributes and the market's prior knowledge about financial reporting problems play important roles in explaining the impact of ICDs. We further find that the negative relation between CAR and CSTD is preserved after controlling for possible simultaneity, but the impact of voluntary disclosure and the information environment on changes in uncertainty become insignificant. The analysis using financial analysts' earnings forecasts dispersion as an alternative proxy for uncertainty confirms the results. Alternative measures of abnormal returns and using a shorter window to calculate the standard deviation of returns do not change the results.

Our main results tabulated in the paper should be interpreted in light of the following caveats. First, to obtain a more stable measure with smaller measurement error, we choose to use a long window for changes in standard deviation instead of a short window with intra-day data, but do not control for confounding events that occur in the entire 120 days before or after the disclosure. Therefore, although we control for earnings announcements and other confounding events around an ICD, we cannot rule out the possibility that events other than the ICD create or resolve the uncertainty changes. Second, because we use long-window standard deviations and short-window returns, the interaction term in the return regression may capture the correlation between current short-window returns and future changes in standard deviation. To address this concern, we replicate the analyses with a three-day window instead of a 120-day window as a sensitivity test and obtain results similar to those tabulated in the paper. However, 
we cannot rule out the possibility that the use of daily-return data instead of intra-day data in calculating short-window standard deviation changes may cause another problem. Third, although we replicate the results with the market-adjusted standard deviations of returns in the sensitivity analysis, we do not use size, industry, or risk-adjusted abnormal changes in the standard deviations. Therefore, it is possible that the standard deviations change because of macro-economic or industry factors.

This study contributes to the accounting literature in the following ways. First, our study demonstrates an important incentive for disclosing internal control deficiencies and shows the impact of such disclosure on market uncertainty. We also show that when a firm discloses its internal control deficiencies, the market's prior knowledge about the credibility of a firm's financial reporting system plays an important role. Second, by providing early evidence on how the new regulatory requirements affect the capital market, our study may help policymakers evaluate the implications of accounting policies and the standard-setting environment. 


\section{References}

Ashbaugh-Skaife, H., Collins, D., and Kinney, W., 2006. The discovery and reporting of internal control deficiencies prior to SOX-mandated audits. Journal of Accounting and Economics 44, 166-192.

Ashbaugh-Skaife, H., Collins, D., Kinney, W., and LaFond, R., 2008. The effect of SOX internal control deficiencies on firm risk and cost of equity capital. Journal of Accounting Research, Forthcoming.

Barron, O., Kim, O., Lim, S., Stevens, D., 1998. Using analysts' forecasts to measure properties of analysts' information environment. The Accounting Review 73, 421-433.

Barron, O., Byard, D., Kim, O., 2002. Changes in analysts' information around earnings announcements. The Accounting Review 77, 821-846.

Beneish, M.D., Billings, M., Hodder, L., 2008. Internal control weakness and information uncertainty. The Accounting Review, 83, 665-703.

Bhojraj, S., Blacconiere, W.G., D'Souza, J.D., 2004. Voluntary disclosure in a multi-audience setting: An empirical investigation. The Accounting Review 79, 921-947.

Botoson, C., 1997. Disclosure level and the cost of equity capital. The Accounting Review 72, 323-349.

Botosan. C., Plumlee, M.A., 2002. A reexamination of disclosure level and the expected cost of equity capital. Journal of Accounting Research 40, 21-40.

Collins, D.W., Kothari, S.P., Rayburn, J.D., 1987. Firm size and information content of prices with respect to earnings. Journal of Accounting and Economics 9, 111-138.

Doyle, J., Ge, W., and McVay, S. 2007a. Determinants of weaknesses in internal control over financial reporting. Journal of Accounting and Economics 44, 193-223.

, and 2007b. Accruals quality and internal control over financial reporting. The Accounting Review 82, 1141-170.

Dye, R.A., 1985. Disclosure of nonproprietary information. Journal of Accounting Research 23, 123-145.

Easley, D., O'Hara, M., 2004. Information and the cost of capital. The Journal of Finance 59, 1553-1583.

Fama, E., and K. French. 1992. The cross-section of expected stock returns. The Journal of Finance $47,427-465$.

Fama, E., and K. French. 1993. Common risk factors in the returns on stocks and bonds. Journal of Financial Economics 33, 3-56.

Franco, G.D., Guan, Y., Lu, H., 2005. The wealth change and redistribution effects of Sarbanes-Oxley internal control disclosures. Working Paper, University of Toronto.

Ge, W., and S. McVay, 2005, The disclosure of material weaknesses in internal control after the Sarbanes-Oxley Act, Accounting Horizons 19, 137-158. 
Hammersley, J., Myers, L., and Shakespeare, C., 2008. Market reactions to the disclosure of internal control weaknesses and to the characteristics of those weaknesses under Section 302 of the Sarbanes Oxley Act of 2002. Review of Accounting Studies 13, 141-166.

Healy, P.M., Palepu, K.G., 1993. The effect of firms' financial disclosure strategies on stock prices. Accounting Horizons 7, 1-11.

Indjejikian, R. 2007. Discussion of accounting information, disclosure, and the cost of capital. Journal of Accounting Research 45, 421-426.

Lambert, R., Leuz, C., Verrecchia, R.E., 2007. Accounting information, disclosure, and cost of capital. Journal of Accounting Research 45, 385-420.

Nichols, D., Smith, D., 1983. Auditor credibility and auditor changes. Journal of Accounting Research 21, 534-544.

Ogneva, M., Subramanyam, K.R., and Raghunanthan, K., 2007. Internal control weakness and cost of equity: evidence from SOX Section 404 certifications. The Accounting Review 82, 1255-1297.

Palmrose, Z., Richardson, V.J., Scholz, S., 2004. Determinants of market reactions to restatement announcements. Journal of Accounting and Economics 37, 59-89.

Sengupta, P., 1998. Corporate disclosure quality and cost of debt. Accounting Review 73, 459-474.

Skinner, D.J., 1994. Why firms voluntarily disclose bad news. Journal of Accounting Research 32, 38-60.

Skinner, D.J., 1997. Earnings disclosure and stockholder lawsuits. Journal of Accounting and Economics $23,249-282$.

Titman, S., Trueman, B., 1986. Information quality and the valuation of new issues. Journal of Accounting and Economics 8, 159-172.

Verrecchia, R.E., 1983. Discretionary disclosure. Journal of Accounting and Economics 5, 179-194.

Willenborg, M., 1999. Empirical analysis of the economic demand for auditing in the initial public offerings market. Journal of Accounting Research 37, 225-238.

Zhang, X.F., 2006, Information uncertainty and stock returns. Journal of Finance 61, 105-136. 


\section{Appendix I \\ Examples of Disclosures of Internal Control Weaknesses}

\section{MATERIAL WEAKNESS}

The company has now determined that the aggregation of its control deficiencies, which include two significant deficiencies, constitute a material weakness ... One of the significant deficiencies relates to the company's controls over its order entry processes, while the other relates to its review of multiple element software license transactions ... The company's management has determined that the identified control deficiencies amount to a material weakness because they believe that these deficiencies, in combination, could result in a more than remote likelihood that a material misstatement of the annual or interim financial statements would not be prevented or detected.

\section{SIGNIFICANT DEFICIENCY}

On September 20, 2004, our independent registered public accounting firm orally notified our management and audit committee that they had identified a significant deficiency regarding our internal controls. The deficiency noted was the lack of segregation of duties within the accounting department. This significant deficiency was not believed to be a material weakness.

\section{RISK FACTORS}

D\&T informed the Audit Committee that they identified the following "reportable conditions" in the design and operation of our internal controls: [1] Deficiencies in our process for determining costs related to deferred profit on shipments to our largest distributor, Future; and [2] Deficiencies in the staffing of our accounting department and related reliance on manual reconciliations and analysis ... 


\section{REMEDIATION}

The Company has made and will continue to make, improvements to its policies, procedures, systems and staff who have significant roles in internal control to address the internal control deficiencies identified by D\&T. Key improvements include hiring a new Chief Financial Officer and Corporate Controller in the third and fourth quarters of 2003, respectively and other financial staff in the fourth quarter of 2003 and the first six months of 2004. The Company will continue to improve and enhance the design of control processes, procedures and upgrade staff to strengthen internal controls. In addition, the Company implemented its enterprise reporting system in its Australian and Netherlands subsidiaries during the first six months of 2004. As of April 30, 2004, the entire Company began operating under one worldwide accounting system. The steps being taken to correct the weaknesses and deficiencies identified by D\&T constitute changes that materially affected the Company's internal control over financial reporting during the most recent fiscal quarter.

\section{POTENTIAL PROBLEMS}

In conjunction with our annual audit for the 2003 year, we identified four potential deficiencies within our internal control framework. The first two relate to segregation of duties deficiencies. The third potential deficiency related to inadequate preparation of supporting documentation to assure the proper timing of accounting for certain transactions involving payroll transfers between multi-state bank accounts. The fourth potential deficiency related to inadequate documentation of approval of certain expenses. 


\section{Appendix II Variable Definitions}

<VARIABLES OF INTEREST $>$

\begin{tabular}{|c|c|}
\hline Variables & Definition \\
\hline$C A R_{-1,1}$ & $\begin{array}{l}\text { Cumulative daily abnormal returns over a } 3 \text {-day event window, day }-1 \text { to }+1 \text {, surrounding } \\
\text { the announcement of internal control problems, estimated from the market-adjusted model. }\end{array}$ \\
\hline$C A R_{-1,0}(0,1)$ & $\begin{array}{l}\text { Cumulative daily abnormal returns over a } 2 \text {-day event window, day }-1 \text { to } 0 \text { (day } 0 \text { to }+1 \text { ), } \\
\text { where the day } 0 \text { is the announcement date of internal control problems. }\end{array}$ \\
\hline$S T D$ & Standard deviation of daily raw stock returns over prior 120 days (-121 to -2$)$. \\
\hline CSTD & $\begin{array}{l}\text { Change in the standard deviation of daily raw stock returns, measured as the difference } \\
\text { between the standard deviations of daily raw stock returns over prior } 120 \text { days }(-121 \text { to }-2) \\
\text { and those after } 120 \text { days of disclosure }(+2 \text { to }+121) \text {. }\end{array}$ \\
\hline D_VOL & $\begin{array}{l}\text { an indicator variable that equals one if the type of ICD is non-material weakness, and zero } \\
\text { otherwise }\end{array}$ \\
\hline D_SUS & $\begin{array}{l}\text { an indicator variable that equals one if an ICD follows events (such as earnings restatements, } \\
\text { management changes, accounting problems) that might give the market a clue about the } \\
\text { firm's financial reporting problems during the six months prior to the internal control } \\
\text { disclosure, zero otherwise. Prior events are identified through a search on the Factiva } \\
\text { database. The type of prior events searched includes earnings restatements, management } \\
\text { change, auditor change, delayed filling, SEC investigation, internal control issues, and other } \\
\text { accounting problems. }\end{array}$ \\
\hline D_INFO & $\begin{array}{l}\text { An indicator variable that equals one if a firm voluntarily releases its internal control } \\
\text { weaknesses when prior suspicious events of the firm are known in the market, zero otherwise. }\end{array}$ \\
\hline$D_{-} E A$ & $\begin{array}{l}\text { An indicator variable that equals one if a firm announces its quarterly or annual earnings } \\
\text { over the nine-day interval beginning (ending) four days before (after) the date of each } \\
\text { internal control disclosure, zero otherwise. }\end{array}$ \\
\hline D_EVENT & $\begin{array}{l}\text { An indicator variable that equals one if a firm releases any confounding news events over the nine- } \\
\text { day interval beginning (ending) four days before (after) the date of each internal control disclosure, } \\
\text { zero otherwise. Confounding news events include earnings announcements, accounting problems } \\
\text { including earnings restatements, management change, auditor change, filling } 10-\mathrm{K} \text { or } 10-\mathrm{Q} \text { reports, } \\
\text { dividend change, stock repurchases, restructuring, security offering announcements, mergers and } \\
\text { acquisitions, spin-offs, large layoffs, SEC allegations, and conference calls. These confounding } \\
\text { news events are identified through a search on Factiva database. }\end{array}$ \\
\hline
\end{tabular}

<CONTROL VARIABLES>

Other Disclosure Attributes:

\begin{tabular}{|l|l|}
\hline Variables & Definition \\
\hline EFFECTIVE & $\begin{array}{l}\text { An indicator variable that equals one if management concludes that the internal controls are } \\
\text { effective, zero otherwise. }\end{array}$ \\
ACCT_SPECIFIC & $\begin{array}{l}\text { An indicator variable that equals one if the internal control weakness is related to any } \\
\text { specific balance sheet/income statement account (generally considered as auditable in the } \\
\text { prior literature), zero otherwise. } \\
\text { An indicator variable that equals one if the internal control disclosure is vague, zero otherwise. } \\
\text { An indicator variable that equals one if the auditor discovered internal control weaknesses, } \\
\text { zero otherwise. }\end{array}$ \\
\hline
\end{tabular}


<CONTROL VARIABLES>

Firm Attributes:

\begin{tabular}{|c|c|}
\hline Variables & Definition \\
\hline$L O G \_S I Z E$ & Log of total assets at the end of 2004. \\
\hline$B M$ & Book-to-market equity ratio at the end of 2004. \\
\hline BETA & $\begin{array}{l}\text { CAPM beta estimated from daily stock returns and value-weighted CRSP market returns in } \\
\text { year } 2003 \text {. }\end{array}$ \\
\hline$A C C E L$ & $\begin{array}{l}\text { An indicator variable that equals one if the firm that discloses its internal control problems is } \\
\text { an accelerated filer as defined by the SEC (market value of equity as of June } 30,2004 \\
>=\$ 75 \text { millions), and zero otherwise. }\end{array}$ \\
\hline LEVERAGE & Book value of long-term debt at the year ending prior to the disclosure, deflated by total assets. \\
\hline$R E T$ & $\begin{array}{l}\text { An indicator variable that equals one if the buy-and-hold market adjusted returns over the } \\
\text { prior } 120 \text { days }(-121 \text { to }-2) \text { is less than zero, zero otherwise. }\end{array}$ \\
\hline NONB4 & $\begin{array}{l}\text { An indicator variable that equals one if the auditor of the firm with disclosure is not one of } \\
\text { BIG } 4 \text { accounting firms, and zero otherwise. }\end{array}$ \\
\hline$L O G \_G O S E G$ & $\begin{array}{l}\text { Log of }(1+\text { sum of the number of geographic segments and the number of operating } \\
\text { segments reported in year } t)\end{array}$ \\
\hline FOREIGN & $\begin{array}{l}\text { An indicator variable that equals one if the firm has a non-zero foreign currency translation } \\
\text { (Compustat data item } \# 150) \text { in year } t \text {, zero otherwise. }\end{array}$ \\
\hline RESTRUCT & $\begin{array}{l}\text { An indicator variable that equals to one if at least one of the following Compustat annual } \\
\text { data items is not equal to zero: } \# 376, \# 377 \text {, } \# 378 \text { or } \# 379 \text {, for any year in year t- } 3 \text { through } \\
\text { year t, zero otherwise. }\end{array}$ \\
\hline SALEGRW & $\begin{array}{l}\text { An indicator variable that equals one if industry-adjusted growth in sales (Compustat data } \\
\text { item \#12) falls into the top quintile in year } t \text {, zero otherwise. }\end{array}$ \\
\hline INVNTRY & $\begin{array}{l}\text { Inventory (Compustat annual data item \#3) over total assets (Compustat annual data item } \\
\text { \#6) in year t }\end{array}$ \\
\hline LOSS & $\begin{array}{l}\text { An indicator variable that equals one if earnings before extraordinary items (Compustat data } \\
\text { item \#18) in year } t-1 \text { and year } t \text { sum to less than zero, zero otherwise. }\end{array}$ \\
\hline RZSCORE & $\begin{array}{l}\text { An indicator variable that equals one if decreasing decile rank of Altman's (1968) Z-Score is } \\
\text { greater than } 7 \text { in year t, zero otherwise. We use decreasing ranks so that larger values } \\
\text { indicate higher bankruptcy probabilities. }\end{array}$ \\
\hline$L O G \_A G E$ & Log of $(1+$ number of years the firm exists in $C R S P$ database $)$ \\
\hline$M \& A$ & $\begin{array}{l}\text { An indicator variable that equals one if a firm is involved in a merger or acquisition from } \\
\text { year } t-2 \text { to year } t \text {, zero otherwise (Compustat AFTNT } \# 1 \text { ). }\end{array}$ \\
\hline LITIGATATION & $\begin{array}{l}\text { An indicator variable that equals one if a firm was in a litigious industry-SIC codes } 2833 \\
\text { to } 2836 ; 3570 \text { to } 3577 ; 3600 \text { to } 3674 ; 5200 \text { to } 5961 \text {; and } 7370 \text {, zero otherwise. }\end{array}$ \\
\hline
\end{tabular}


TABLE 1

Descriptive Statistics

Panel A: Cumulative abnormal returns of the full sample

\begin{tabular}{|c|c|c|c|c|c|c|c|}
\hline \multirow[b]{2}{*}{ Variables } & \multirow[b]{2}{*}{ Mean } & \multirow[b]{2}{*}{ Median } & \multirow[b]{2}{*}{ STD } & \multirow[b]{2}{*}{ Q1 } & \multirow[b]{2}{*}{ Q3 } & \multicolumn{2}{|c|}{$P$-value } \\
\hline & & & & & & t-test & Wilcoxon-test \\
\hline CAR-1,1 & -0.0132 & -0.0051 & 0.0828 & -0.0383 & 0.02 & 0.0017 & 0.0023 \\
\hline CAR-1,0 & -0.0087 & -0.0064 & 0.0669 & -0.0263 & 0.018 & 0.0106 & 0.0055 \\
\hline CAR 0,1 & -0.0085 & -0.0041 & 0.0626 & -0.0301 & 0.0188 & 0.0077 & 0.0199 \\
\hline
\end{tabular}

Panel B: Proxies for market uncertainty and uncertainty change

Folded F-test p-values

\begin{tabular}{|c|c|c|c|c|c|c|c|c|c|}
\hline \multirow{2}{*}{\multicolumn{2}{|c|}{$\underline{\text { STD }}$}} & \multirow{2}{*}{\multicolumn{2}{|c|}{$\underline{\text { STDaf }}$}} & \multirow{2}{*}{\multicolumn{2}{|c|}{$\underline{\text { CSTD }}$}} & & & \multirow{3}{*}{$\begin{array}{l}\# \text { of p-value } \\
<0.05 \text { with } \\
\text { CSTD }>0\end{array}$} & \multirow{3}{*}{$\begin{array}{l}\# \text { of p-value } \\
<0.05 \text { with } \\
\text { CSTD }<0\end{array}$} \\
\hline & & & & & & & & & \\
\hline Mean & Median & Mean & Median & Mean & Median & Mean & Median & & \\
\hline 0.0333 & 0.0306 & 0.0324 & 0.0261 & -0.0010 & -0.0027 & 0.2031 & 0.0358 & 61 & 136 \\
\hline
\end{tabular}

Panel C: Disclosures by Industry

\begin{tabular}{llrr} 
Industry & Codes & Freq & $\%$ \\
\hline Oil and Gas & 13 & 10 & 2.54 \\
Food Products & 20 & 8 & 2.03 \\
Paper and Paper Products & $24-27$ & 8 & 2.03 \\
Chemical Products & 28 & 21 & 5.33 \\
Manufacturing & $30-34$ & 19 & 4.82 \\
Computer Equipment and Services & 35,73 & 92 & 23.35 \\
Electronic Equipment & 36 & 43 & 10.92 \\
Transportation & $37,39,40-42,44,45$ & 20 & 5.08 \\
Scientific Instruments & 38 & 23 & 5.84 \\
Communications & 48 & 18 & 4.57 \\
Electricity, Gas, and Sanitary Services & 49 & 14 & 3.55 \\
Durable Goods & 50 & 11 & 2.79 \\
Retail & $53,54,56,57,59$ & 19 & 4.82 \\
Eating and Drinking Establishments & 58 & 3 & 0.76 \\
Financial & $60,61,63-65,67$ & 37 & 9.39 \\
Entertainment services & $70,78,79$ & 6 & 1.52 \\
Health & 80 & 6 & 1.52 \\
All others & & 36 & 9.14 \\
\hline Total & & 394 & 100.00 \\
\hline
\end{tabular}

See Appendix II for variable definitions. 
TABLE 2

Univariate Analysis

Panel A: CAR -1, $1_{\text {by }}$ Change in the Standard Deviation of Stock Returns

\begin{tabular}{lcrrrr} 
& & & \multicolumn{2}{c}{ P-value } \\
\cline { 5 - 6 } Change in the standard deviation $(C S T D)$ & OBS & Mean & Median & t-test & Wilcoxon-test \\
\hline Decrease & 247 & -0.0039 & -0.0013 & 0.3272 & 0.4041 \\
Increase & 147 & -0.0290 & -0.0125 & 0.0015 & 0.0001 \\
\hline Total & 394 & & & &
\end{tabular}

Panel B: CAR $-1,1$ by Disclosure Types

\begin{tabular}{|c|c|c|c|c|c|c|}
\hline \multirow[b]{2}{*}{ Type } & \multirow[b]{2}{*}{ Description } & \multirow[b]{2}{*}{ OBS } & \multirow[b]{2}{*}{ Mean } & \multirow[b]{2}{*}{ Median } & \multicolumn{2}{|c|}{ P-value } \\
\hline & & & & & t-test & Wilcoxon-test \\
\hline 1 & Material weakness & 227 & -0.0194 & -0.0078 & 0.0013 & 0.0015 \\
\hline 2 & Deficiencies & 95 & -0.0029 & -0.0004 & 0.7134 & 0.8448 \\
\hline 3 & Risk factors & 21 & -0.0148 & -0.0120 & 0.2508 & 0.1995 \\
\hline 4 & Remediation & 38 & 0.0127 & -0.0069 & 0.3290 & 0.6746 \\
\hline 5 & $\begin{array}{l}\text { Lack of IC, potential } \\
\text { problems, allegation }\end{array}$ & 13 & -0.0541 & -0.0176 & 0.0680 & 0.1099 \\
\hline & Total & 394 & & & & \\
\hline & & & t-test & Wilcoxon-test & & \\
\hline & & & t-value (p-value) & Z-value (p-value) & & \\
\hline & Type 1 versus Type 2 & & $-2.73(0.0067)$ & $2.31(0.0105)$ & & \\
\hline & Type 1 versus Type 3 & & $-0.21(0.8301)$ & $-0.16(0.4377)$ & & \\
\hline & Type 1 versus Type 4 & & $-2.59(0.0103)$ & $-1.70(0.0450)$ & & \\
\hline & Type 1 versus Type 5 & & $0.51(0.6105)$ & $0.51(0.3043)$ & & \\
\hline
\end{tabular}

\section{Panel C: CAR $_{-1,1}$ Partitioned by Disclosure Types and Change in the Standard Deviation}

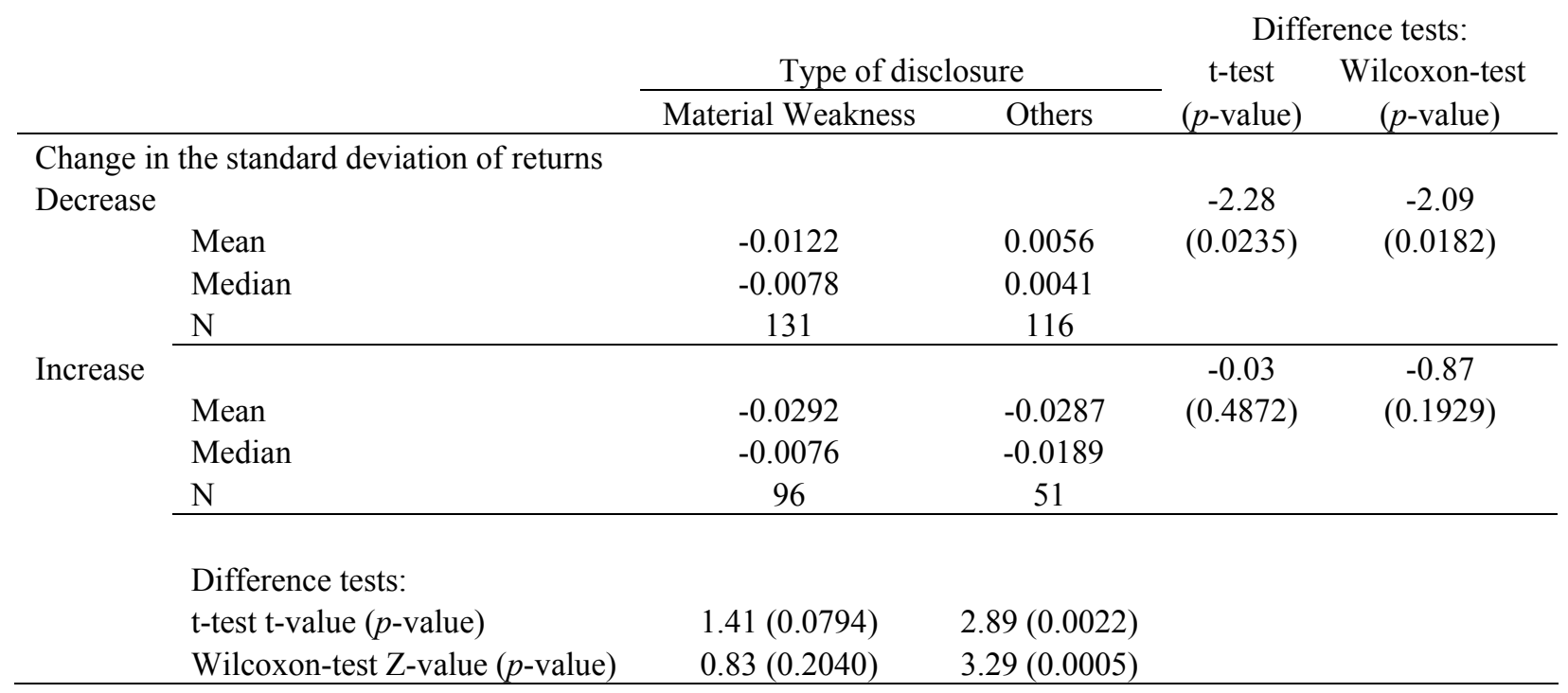




\section{TABLE 2 (continued)}

Panel D: Change in the Standard Deviation and CAR $\mathbf{C l}_{1,1}$ by Disclosure Types and Prior Suspicious Events

\begin{tabular}{|c|c|c|c|c|c|}
\hline \multirow[b]{3}{*}{ Market's prior knowledge } & & \multicolumn{4}{|c|}{ Type of disclosure } \\
\hline & & \multicolumn{2}{|c|}{ Material Weakness } & \multicolumn{2}{|c|}{ Others } \\
\hline & & Mean & Median & Mean & Median \\
\hline \multirow[t]{7}{*}{ With suspicious events } & $C S T D$ & 0.0031 & -0.0017 & -0.0058 & -0.0055 \\
\hline & $\mathrm{N}$ & \multicolumn{2}{|c|}{55} & \multicolumn{2}{|c|}{27} \\
\hline & Folded- F-test p-values & & & \multirow{2}{*}{\multicolumn{2}{|c|}{0.0287}} \\
\hline & Mean & \multicolumn{2}{|c|}{0.2290} & & \\
\hline & Median & \multicolumn{2}{|c|}{0.0669} & \multicolumn{2}{|c|}{0.0197} \\
\hline & \# of sig. $<0.05$ with $\mathrm{CSTD}>0$ & \multicolumn{2}{|c|}{11} & \multicolumn{2}{|c|}{2} \\
\hline & \# of sig. $<0.05$ with $\mathrm{CSTD}<0$ & \multicolumn{2}{|c|}{14} & \multicolumn{2}{|c|}{14} \\
\hline \multirow[t]{7}{*}{ Without suspicious events } & CSTD & 0.0004 & -0.0019 & -0.0034 & -0.0032 \\
\hline & $\mathrm{N}$ & \multicolumn{2}{|c|}{172} & \multicolumn{2}{|c|}{140} \\
\hline & Folded- F-test p-values & & & & \\
\hline & Mean & \multicolumn{2}{|c|}{0.2028} & \multicolumn{2}{|c|}{0.2270} \\
\hline & Median & \multicolumn{2}{|c|}{0.0257} & \multicolumn{2}{|c|}{0.0497} \\
\hline & $\#$ of sig. $<0.05$ with $\mathrm{CSTD}>0$ & \multicolumn{2}{|c|}{30} & \multicolumn{2}{|c|}{18} \\
\hline & \# of sig. $<0.05$ with $\mathrm{CSTD}<0$ & \multicolumn{2}{|c|}{61} & \multicolumn{2}{|c|}{47} \\
\hline
\end{tabular}

Type of disclosure

\begin{tabular}{|c|c|c|c|c|c|c|c|}
\hline \multirow[b]{3}{*}{ Market's prior knowledge } & & \multicolumn{4}{|c|}{ Type of disclosure } & \multicolumn{2}{|c|}{ Difference tests: } \\
\hline & & \multicolumn{2}{|c|}{ Material Weakness } & \multicolumn{2}{|c|}{ Others } & \multirow{2}{*}{$\begin{array}{c}\text { t-test } \\
\text { (p-value) }\end{array}$} & \multirow{2}{*}{$\begin{array}{c}\text { Wilcoxon-test } \\
\text { (p-value) }\end{array}$} \\
\hline & & Mean & Median & Mean & Median & & \\
\hline \multirow[t]{2}{*}{ With suspicious events } & $C A R_{-1,1}$ & -0.0249 & -0.0077 & 0.0130 & 0.0083 & $\begin{array}{c}-1.80 \\
(0.0748)\end{array}$ & $\begin{array}{c}-1.44 \\
(0.0750)\end{array}$ \\
\hline & $\mathrm{N}$ & \multicolumn{2}{|c|}{55} & \multicolumn{2}{|c|}{27} & & \\
\hline Without suspicious events & $C A R_{-1,1}$ & -0.0176 & -0.0087 & -0.0083 & -0.0024 & $\begin{array}{c}-1.21 \\
(0.2254)\end{array}$ & $\begin{array}{c}-1.16 \\
(0.1234)\end{array}$ \\
\hline
\end{tabular}

Difference tests:

t-test: t-value $(p$-value) $\quad-1.21(0.2282) \quad 1.36(0.1772)$

Wilcoxon-test: Z-value ( $p$-value) $\quad-0.84(0.2000) \quad 0.82(0.2058)$ 


\section{TABLE 2 (continued)}

See Appendix II for variable definitions.

In Panel A, the sample is partitioned into two groups: disclosure that decreases the standard deviation of daily stock returns and those that increase the standard deviation of daily stock returns. In Panel B, the sample is partitioned based on type of internal control deficiency disclosure. In Panel C, the sample is partitioned into four groups based on changes in the standard deviation of returns and types of disclosure. In Panel D, the sample is partitioned into four groups based on type of disclosure and the incidence of events during the six months prior to the disclosure of internal control deficiencies that would make the market participants to suspect internal control deficiencies. One-tailed difference test p-values are in parentheses. 
TABLE 3

Market Reaction to ICD and Changes in Uncertainty $(\mathrm{N}=275)$

$$
C A R=a 0+a 1 C S T D+a 2 S T D+\sum_{i=1}^{n} \gamma_{i} \text { Control Variables }_{i}
$$

\begin{tabular}{|c|c|c|c|c|}
\hline \multirow[b]{2}{*}{ Intercept } & \multicolumn{2}{|l|}{1} & \multicolumn{2}{|l|}{2} \\
\hline & $\begin{array}{r}0.0056 \\
(0.52)\end{array}$ & & $\begin{array}{r}0.0375 \\
(1.15)\end{array}$ & \\
\hline CSTD & -0.6025 & $* *$ & -0.9678 & $* * *$ \\
\hline$S T D$ & $\begin{array}{r}-0.6276 \\
(-2.09)\end{array}$ & $* *$ & $\begin{array}{r}-0.8858 \\
(-2.31)\end{array}$ & $* *$ \\
\hline $\begin{array}{l}\text { Other Disclosure Attrib } \\
\text { EFFECTIVE }\end{array}$ & & & $\begin{array}{r}0.0134 \\
(0.95)\end{array}$ & \\
\hline$A C C T \_S P E C I F I C$ & & & $\begin{array}{r}0.0036 \\
(0.37)\end{array}$ & \\
\hline VAGUE & & & $\begin{array}{r}-0.0352 \\
(-2.23)\end{array}$ & $* *$ \\
\hline AUDIT_IDENTIFIED & & & $\begin{array}{r}-0.0087 \\
(-0.90)\end{array}$ & \\
\hline Firm Attributes: & No & & Yes & \\
\hline Industry Dummies & No & & Yes & \\
\hline Adjusted $R^{2}$ & 0.0373 & & 0.0440 & \\
\hline
\end{tabular}

$C A R=$ cumulative daily abnormal returns over a 3-day event window, day -1 to +1 , surrounding the announcement of internal control problems, estimated from the market-adjusted model.

CSTD = change in the standard deviation of daily raw stock returns, measured as the difference between the standard deviations of daily raw stock returns over prior 120 days $(-121$ to -2$)$ and those after 120 days of disclosure ( +2 to +121$)$.

$S T D=$ standard deviation of daily raw stock returns over prior 120 days $(-121$ to -2$)$.

See Appendix II for definitions of other variables.

$*, * *$, and $* * *$ denote statistical significance at the $0.10,0.05$, and 0.01 level, respectively. 
TABLE 4

Change in Uncertainty, Voluntary ICD, and Information Environment (N=275)

\begin{tabular}{|c|c|c|c|c|c|c|c|c|}
\hline \multirow{3}{*}{$\begin{array}{l}C S T D=a 0+a 1 S T D+ \\
\text { Intercept }\end{array}$} & \multicolumn{7}{|c|}{$\sum_{i=1}^{n} \gamma_{i}$ Control Variables $_{i}$} & \multirow[t]{2}{*}{ (2) } \\
\hline & 1 & & 2 & & 3 & & 4 & \\
\hline & $\begin{array}{r}0.0001 \\
(0.02)\end{array}$ & & $\begin{array}{r}0.0092 \\
(1.62)\end{array}$ & & $\begin{array}{r}-0.0004 \\
(-0.25)\end{array}$ & & $\begin{array}{r}-0.0012 \\
(-0.28)\end{array}$ & \\
\hline STD & $\begin{array}{r}-0.0571 \\
(-1.71)\end{array}$ & $*$ & $\begin{array}{r}-0.1366 \\
(-1.92)\end{array}$ & $*$ & $\begin{array}{r}-0.0890 \\
(-2.54)\end{array}$ & $* *$ & $\begin{array}{r}-0.1629 \\
(-3.24)\end{array}$ & $* * *$ \\
\hline$D_{-} V O L$ & $\begin{array}{r}-0.0024 \\
(-2.31)\end{array}$ & $* *$ & $\begin{array}{r}-0.0035 \\
(-2.00)\end{array}$ & $* *$ & $\begin{array}{r}-0.0001 \\
(-0.01)\end{array}$ & & $\begin{array}{r}0.0009 \\
(0.62)\end{array}$ & \\
\hline D_SUS & & & & & $\begin{array}{r}0.0016 \\
(0.95)\end{array}$ & & $\begin{array}{r}0.0019 \\
(1.09)\end{array}$ & \\
\hline$D \_V O L * D \_S U S$ & & & & & $\begin{array}{r}-0.0058 \\
(-2.15)\end{array}$ & $* *$ & $\begin{array}{r}-0.0059 \\
(-2.07)\end{array}$ & $* *$ \\
\hline Other Disclosure Attrib & & & & & & & & \\
\hline EFFECTIVE & & & $\begin{array}{r}-0.0028 \\
(-0.98)\end{array}$ & & & & $\begin{array}{r}0.0003 \\
(0.13)\end{array}$ & \\
\hline$A C C T \_S P E C I F I C$ & & & $\begin{array}{r}-0.0001 \\
(-0.00)\end{array}$ & & & & $\begin{array}{r}0.0011 \\
(0.67)\end{array}$ & \\
\hline$V A G U E$ & & & $\begin{array}{r}0.0033 \\
(1.28)\end{array}$ & & & & $\begin{array}{r}0.0014 \\
(0.73)\end{array}$ & \\
\hline AUDIT_IDENTIFIED & & & $\begin{array}{r}0.0017 \\
(0.88)\end{array}$ & & & & $\begin{array}{r}0.0017 \\
(1.21)\end{array}$ & \\
\hline Firm Attributes: & No & & Yes & & No & & Yes & \\
\hline Industry Dummies & No & & Yes & & No & & Yes & \\
\hline
\end{tabular}

\begin{tabular}{lllll} 
Adjusted $R^{2}$ & 0.0202 & 0.0304 & 0.0338 & 0.0725 \\
\hline
\end{tabular}

Marginal effect of voluntary disclosure in the context of prior suspicious events ( $a 2+a 4)$ :

$\begin{array}{lrr}\text { F statistic } & 5.87 & 3.95 \\ \text { p-value } & 0.0161 & 0.0482\end{array}$

Marginal effect of prior suspicious events in the case of voluntary disclosure (a3 $+\mathrm{a} 4)$ :

$\begin{array}{lrr}\text { F statistic } & 3.99 & 3.17 \\ \text { p-value } & 0.0469 & 0.0764\end{array}$

CSTD = change in the standard deviation of daily raw stock returns, measured as the difference between the standard deviations of daily raw stock returns over prior 120 days $(-121$ to -2$)$ and those after 120 days of disclosure ( +2 to +121$)$.

$S T D=$ standard deviation of daily raw stock returns over prior 120 days $(-121$ to -2$)$.

$D_{-} V O L=$ an indicator variable that equals one if a firm discloses its internal control deficiencies other than material weakness, zero otherwise.

D_SUS $=$ an indicator variable that equals one if there exist prior suspicious events for a firm (such as earnings restatement, management change, accounting problems) that might give the market a clue about the firm's internal control deficiency during the six months prior to the internal control disclosure, zero otherwise. Prior events are identified through a search on Factiva database. The type of prior events searched includes earnings restatements, management change, auditor change, delayed filling, SEC investigation, internal control issues, and other accounting problems.

See Appendix II for definitions of other variables.

$*, * *$, and $* * *$ denote statistical significance at the $0.10,0.05$, and 0.01 level, respectively. 
TABLE 5

Market Reaction to ICD after Controlling for Prior Suspicious Events and Other Confounding Events (N=275)

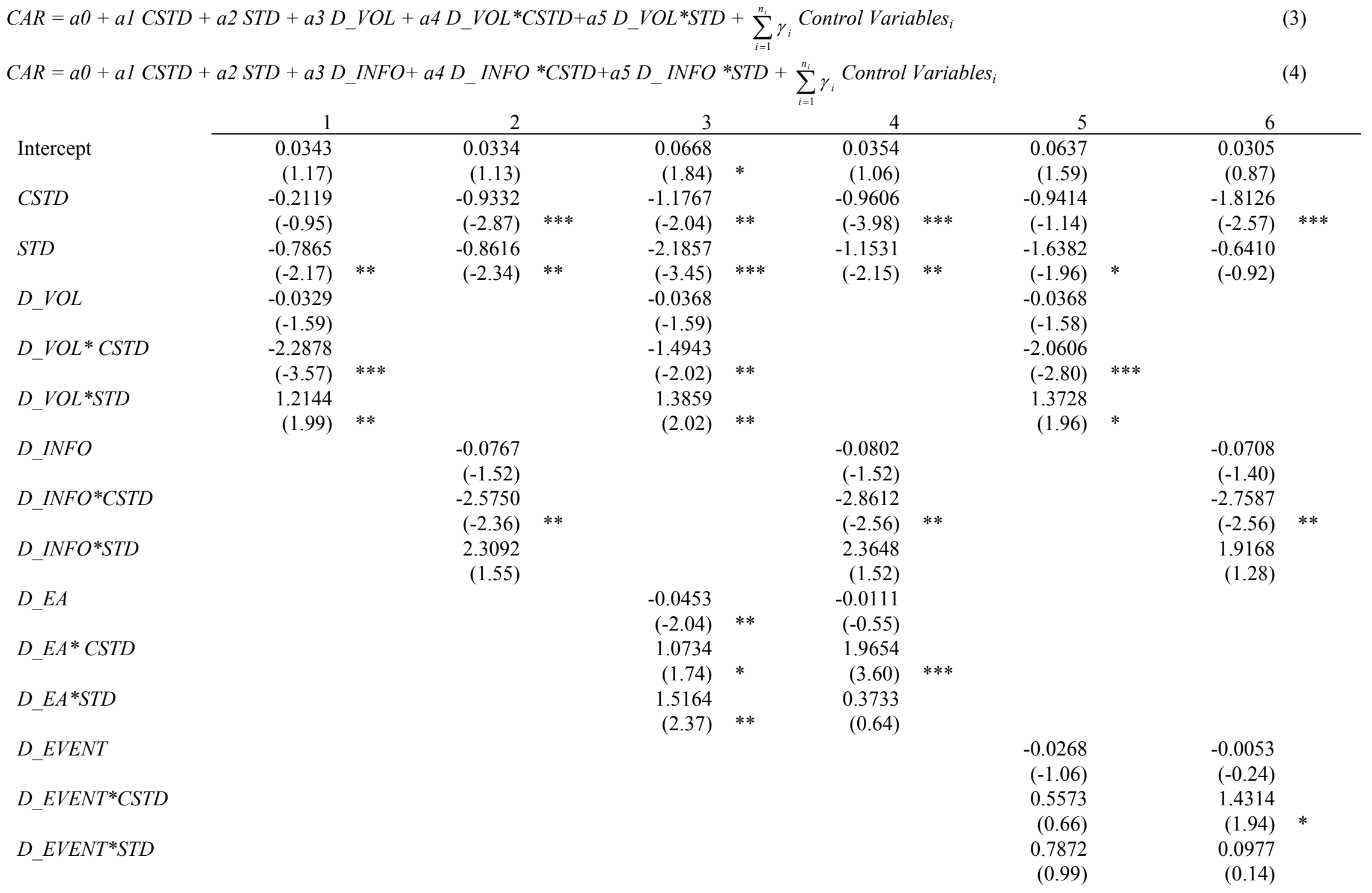




\section{TABLE 5: continued}

Other Disclosure Attributes:

EFFECTIVE
VAGUESPECIFIC

0.0090

(0.70)

0.0058

$(0.27)$
$-0.0029)$

0.0046

$(0.33)$

(0.65)

0.0063

$-0.0030$

(0.64) (-0.34)

$(0.66) \quad(-0.34)$

$(-0.34)$
-0.0282

$(-2.77) \quad * * *$

$(-2.04)$

AUDIT_IDENTD

$-0.0058$

$-0.0079$

$-0.0357$

$(-2.29)$

$-0.0294$

$(-0.65)$

$(-0.93)$

$-0.0049$

$(-2.00)$

$(-0.49)$

$-0.0091$

$(-1.02)$

Yes

Yes

Yes

Yes

Yes

0.0109

(0.78)

0.0048

(0.49)

$-0.0371$

$(-2.38)$

$-0.0043$

$(-0.43)$

Yes

0.0041

(0.31)

$-0.0028$

$(-0.32)$

Industry Dummies

Yes

Yes

Yes

$(-1.75)$

$-0.0082$

(-0.95)

Yes

Yes

Adjusted $R^{2}$

0.0823

0.0812

0.0713

0.1000

0.0726

0.0749

$C A R=$ cumulative daily abnormal returns over a 3 -day event window, day -1 to +1 , surrounding the announcement of internal control problems, estimated from the marketadjusted model.

$C S T D=$ change in the standard deviation of daily raw stock returns, measured as the difference between the standard deviations of daily raw stock returns over prior 120 days $(-$ 121 to -2$)$ and those after 120 days of disclosure ( +2 to +121$)$.

$S T D=$ standard deviation of daily raw stock returns over prior 120 days $(-121$ to -2$)$.

D $V O L=$ an indicator variable that equals one if a firm discloses its internal control deficiencies other than material weakness, zero otherwise.

$D_{-} I N F O=$ an indicator variable that equals one if a firm voluntarily releases its internal control weaknesses when prior suspicious events of the firm are known in the market, zero otherwise.

$D_{-} E A=$ an indicator variable that equals one if a firm announces its quarterly or annual earnings over the nine-day interval beginning (ending) four days before (after) the date of each internal control disclosure, zero otherwise.

$D_{-} E V E N T=$ an indicator variable that equals one if a firm releases any confounding news events over the nine-day interval beginning (ending) four days before (after) the date of each internal control disclosure, zero otherwise. Confounding news events include earnings announcements, accounting problems including earnings restatements, management change, auditor change, filling 10-K or 10-Q reports, dividend change, stock repurchases, restructuring, security offering announcements, mergers and acquisitions, spin-offs, large layoffs, SEC allegations, and conference calls. These confounding news events are identified through a search on Factiva database.

See Appendix II for definitions of other variables.

$*, * *$, and $* * *$ denote statistical significance at the $0.10,0.05$, and 0.01 level, respectively. 
TABLE 6

Simultaneous Equation Models of Changes in Uncertainty and Abnormal Returns around ICD (N=275)

$$
\begin{aligned}
& C A R=a 0+a 1 C S T D+a 2 S T D+a 3 D_{-} \text {VOL }(\text { or D_INFO })+a 4 D_{-} E A(\text { or D_EVENT })+\sum_{i=1}^{n_{i}} \gamma_{i} \text { Control Variables }_{i} \\
& C S T D=b 0+b 1 C A R+b 2 S T D+b 3 D_{-} \text {VOL }(\text { or D_INFO })+b 4 D_{-} E A(\text { or D_EVENT })+\sum_{j=1}^{n_{j}} \delta_{j} \text { Control Variables }_{j}
\end{aligned}
$$

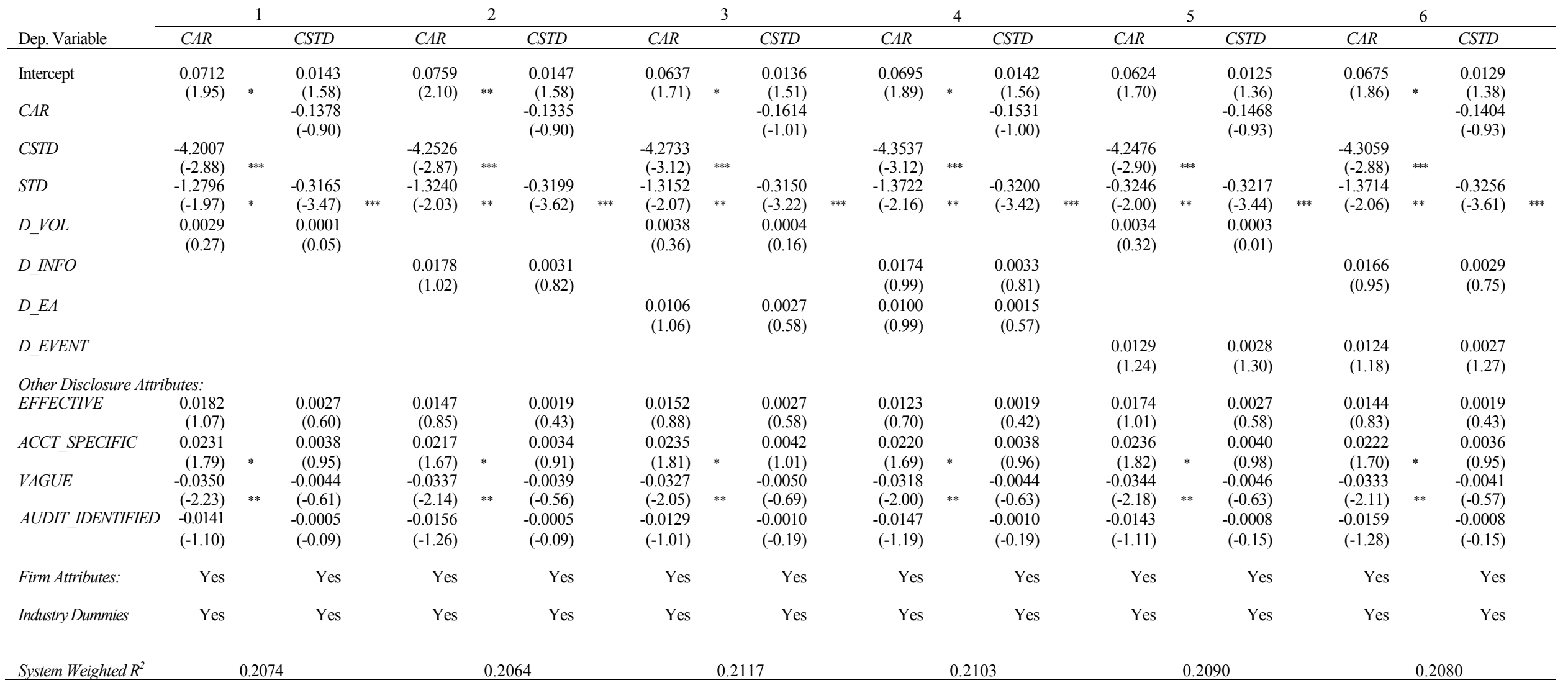

See Appendix II for variable definitions.

$*, * *$, and $* * *$ denote statistical significance at the $0.10,0.05$, and 0.01 level, respectively. 
FIGURE 1

Underlying Relations among Internal Control Disclosures, Uncertainty, and Abnormal Returns

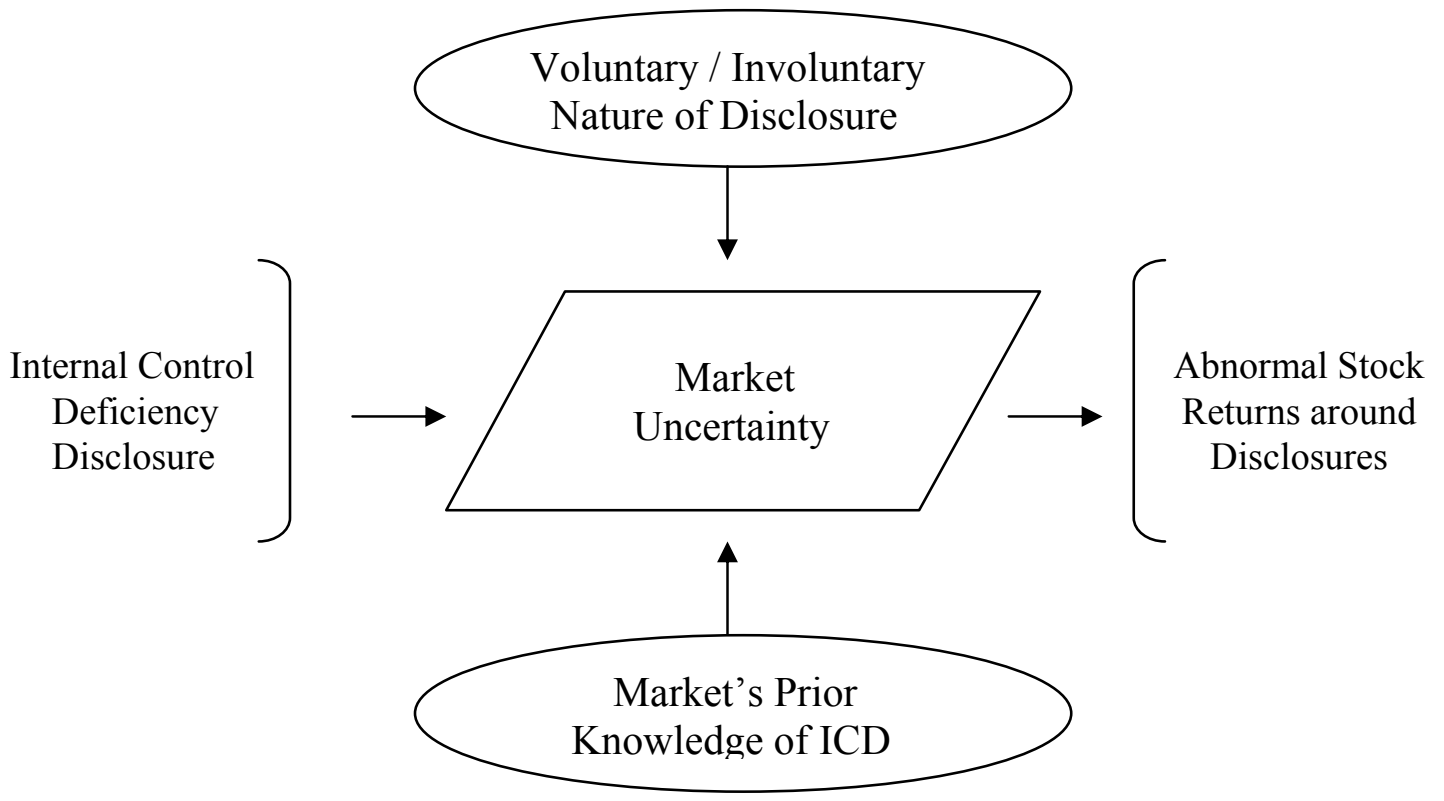


FIGURE 2

Distribution of Disclosure of Internal Control Deficiencies under Section 302 by Month (2004)

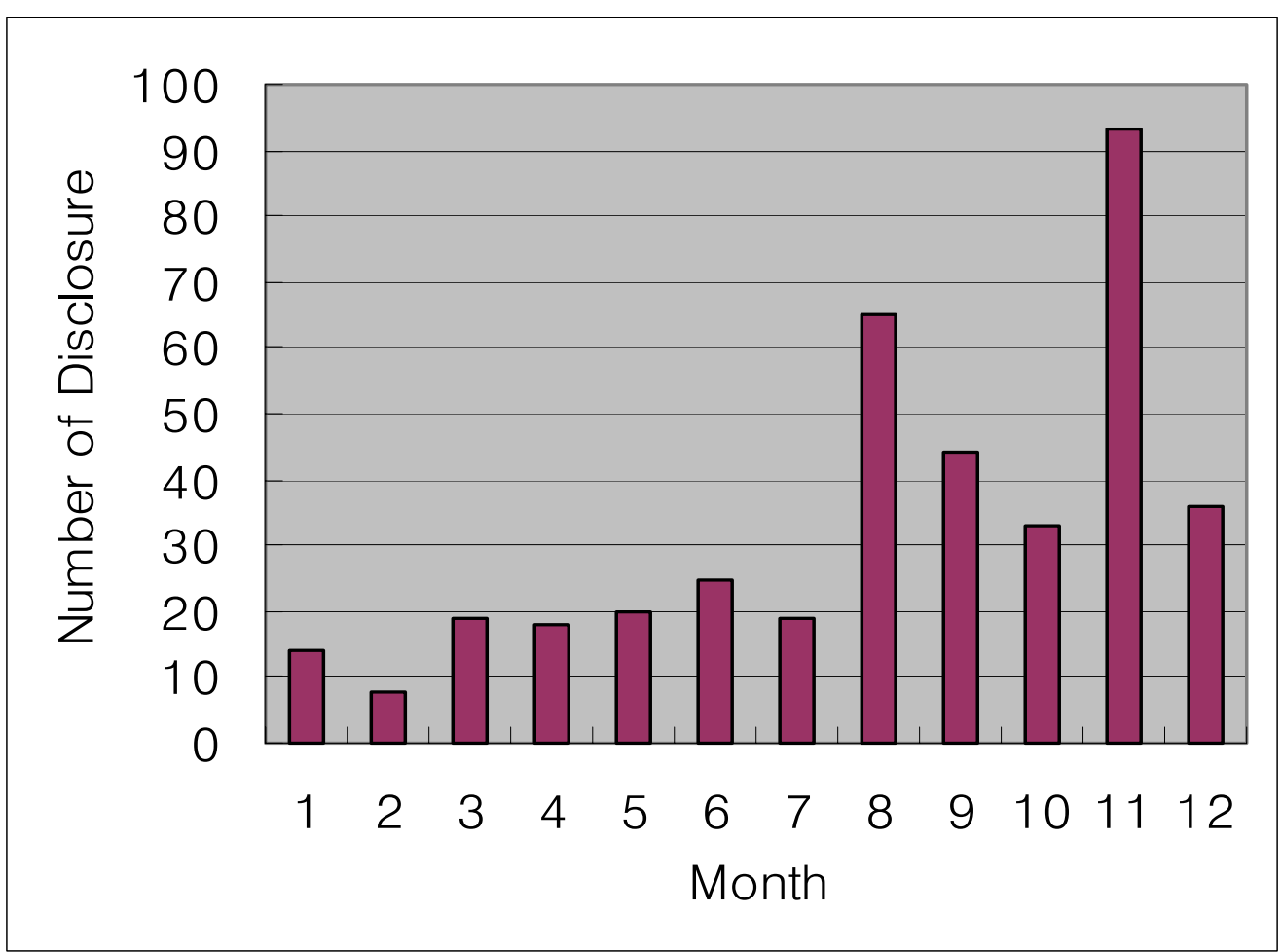

